\title{
ANÁLISE FACIOLÓGICA E DEPOSICIONAL DOS DEPÓSITOS FLÚVIO- EÓLICOS DA FORMAÇÃO SÃO SEBASTIÃO (EOCRETÁCEO), REGIÃO DE CAMPOS-IBIMIRIM, BACIA DE JATOBÁ, PE, NORDESTE DO BRASIL
}

\author{
FACIOLOGICAL AND DEPOSITIONAL ANALYSIS OF THE FLUVIAL-EOLIC DEPOSITS OF \\ THE SÃO SEBASTIÃO FORMATION (EOCRETACEOUS), CAMPOS-IBIMIRIM REGION, \\ JATOBÁ BASIN, PE, NORTHEAST BRAZIL
}

\begin{abstract}
Gelson Luís FAMBRINI ${ }^{1}$, Dunaldson Eliezer Gomes Alcoforado da ROCHA ${ }^{2}$, Edison Vicente OLIVEIRA $^{1 *}$, Patricia Celeste Lopes JESUÍNO ${ }^{3}$, José Acioli Bezerra de MENEZES-FILHO ${ }^{4}$, Renan Gustavo Barbosa QUEIROZ ${ }^{5}$, Virginio Henrique de Miranda Lopes NEUMANN ${ }^{*}$

${ }^{1}$ Departamento de Geologia, Centro de Tecnologia e Geociências, Universidade Federal de Pernambuco. Avenida Acadêmico Hélio Ramos s/n. Cidade Universitária, Recife, Pernambuco. Email: gelson.fambrini@ufpe.br, neumann@ufpe.br, edison.vicente@ufpe.br)

${ }^{2}$ Companhia de Pesquisa de Recursos Minerais/Serviço Geológico do Brasil-Recife - PE. Email: dunaldson@msn.com

${ }^{3}$ Geóloga autônoma. Email: patrícia_clj@hotmail.com

${ }^{4}$ Instituto de Tecnologia de Pernambuco (ITEP), Recife, Pernambuco. Email: joseacioli@gmail.com

${ }^{5}$ Pós-Graduação em Geociências (PPGeoc-UFPE). Email: renanqueiroz88@hotmail.com

*Bolsista de produtividade em pesquisa do Conselho Nacional de Pesquisa e Desenvolvimento (CNPq-Brasil)
\end{abstract}

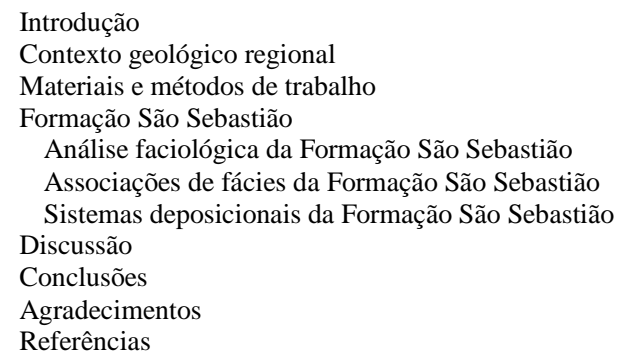

RESUMO - A Bacia de Jatobá pertence ao denominado Rifte Recôncavo-Tucano-Jatobá, estrutura geotectônica constituída por extenso rifte abortado no Cretáceo durante as fases de fragmentação do Supercontinente Gondwana. Este trabalho enfoca inédita análise de fácies e sistemas deposicionais da Formação São Sebastião (Eocretáceo). As fácies foram identificadas segundo a litologia predominante, geometria dos corpos, estruturas sedimentares e padrão de paleocorrentes. As principais litofácies reconhecidas foram: (i) conglomerados sustentados pelo arcabouço e arenitos grossos a médios, conglomeráticos com estratificações cruzadas acanaladas de pequeno porte, ou maciços; (ii) arenitos grossos a médios com estratificações cruzadas acanaladas de médio e grande porte; (iii) arenitos médios com boa seleção e estratificação plano-paralela e (iv) arenitos médios com estratificação cruzada tabular de médio porte, bem selecionados. As fácies (i) foram interpretadas como geradas por sistemas fluviais entrelaçados efêmeros. O conjunto de fácies (ii), (iii) e (iv) foi interpretado como originado em campo de dunas eólicas, lençóis de areia eólica e interduna. A Formação São Sebastião representa a interação de dois sistemas deposicionais: eólico e fluvial. As características sedimentológicas dos arenitos da Formação São Sebastião indicam ambiente de sedimentação inicialmente fluvial, com posterior retrabalhamento por vento, e a superior, um ambiente desértico, tipicamente eólico, com interações fluviais.

Palavras-chave: fácies flúvio-eólicas, sistemas deposicionais, estratigrafia, Cretáceo, Bacia de Jatobá.

\begin{abstract}
The Jatobá basin belongs to the Recôncavo -Tucano-Jatobá Rift System, an extensive tectonic structure aborted in the Cretaceous during the fragmentation and dispersion of the Supercontinent Gondwana. This work focuses on unpublished analysis of fácies and depositional systems of the São Sebastião Formation (Eocretaceous).The fácies were identified according to the dominant lithology, geometry of sedimentary bodies, structures and pattern of paleocurrents. The main lithofácies recognized were: (i) clast supported conglomerates and coarse to medium sandstones, conglomeratic, with small trough cross-stratifications, or even massive; (ii) coarse to medium sandstones with medium to very large trough cross-stratifications, and pinstripe lamination; (iii) well sorted medium sandstones with horizontal stratification and (iv) well sorted medium sandstones with small to medium planar crossstratifications. The set of fácies (ii), (iii) and (iv) was interpreted as originated by process involving dune fields, sand dunes and interdune deposits, typically aeolian. The São Sebastião Formation represents the interaction of two depositional systems: aeolian and fluvial. The sedimentological characteristics of sandstones of the São Sebastião Formation indicate sedimentation environment initially fluvial, with subsequent reworking by wind, and the superior part, a desert environment, typically aeolian, with fluvial interactions. Keywords: fluvial-aeolian fácies, depositional systems, stratigraphy, Cretaceous, Jatobá Basin.
\end{abstract}

\section{INTRODUÇÃO}

Formação São Sebastião tem sido considerada como a unidade que finaliza a fase rifte do sistema tafrogênico das bacias de Recôncavo,
Tucano e Jatobá, RTJ (Magnavita, 1992; Caixeta et al., 1994; Costa et al., 2007; Magnavita et al., 2012), tendo sido definida na Bacia do 
Recôncavo e, posteriormente, mapeada e estendida para as bacias de Tucano e Jatobá. No entanto, trabalhos recentes (Figueiredo et al., 2016; Freitas et al. 2017) questionaram esse postulado e interpretaram que o aparecimento de subsidência térmica na base da Formação Marizal implicaria em atividade contínua do rifte durante o Cretáceo, no contexto do Atlântico Sul.

Para o topo da Sequência Rifte há o predomínio de fácies fluviais incluídas, por exemplo, na Formação São Sebastião, a despeito da presença de fácies fluviais desde as fases iniciais do rifteamento. Tal preponderância de fácies fluviais testemunha a fase final de assoreamento do rifte, que durante o Andar Jiquiá esteve submetido a um novo ciclo tectônico, com a criação e a reativação de falhamentos (Aragão \& Peraro, 1994). As maiores taxas de subsidência são compensadas, no entanto, por elevadas taxas de aporte sedimentar, resultando em uma sucessão estratigráfica de caráter agradacional, com preservação de espessas seções fluviais.

A Formação São Sebastião possui exposições em todo o sistema rifte RTJ. Na Bacia de Tucano, a Formação São Sebastião apresenta espessura máxima superior a $3.000 \mathrm{~m}$, constituída por arenitos conglomeráticos e conglomerados de origem fluvial, com menor abundância de estratos pelíticos e de heterolíticos (Costa et al., 2007; Figueiredo, 2013; Figueiredo et al., 2016). De acordo com Figueiredo et al. (2016), a maioria da sucessão da Formação São Sebastião na Sub-bacia de Tucano Central é composta por depósitos fluviais com barras grandes, formando corpos de areia tabulares de espessura métrica internamente com estratificações cruzadas compostos, definidos por conjuntos de estratos inclinados de arenitos com estratificações cruzadas, com abundante enrolar estratos. Localmente depósitos de Dunas Eólicas podem ocorrer, caracterizados por arenitos médios a finos com estratificações cruzadas de até $15 \mathrm{~m}$ espessura (Figueiredo, 2013). Na Bacia de Jatobá a ocorrência de depósitos fluviais é reduzida, com abundância de formas eólicas, como veremos.

Entretanto, a presença de depósitos eólicos na Formação São Sebastião na Bacia de Jatobá, reconhecida e mapeada pela CPRM-Recife (Rocha \& Leite, 1999), e analisada por Fambrini et al. (2013) e Ferronatto (2016), tem sido pouco estudada. Os estudos geológicos de forma geral na Formação São Sebastião ao longo de todo o rifte do RTJ são escassos. As investigações centraram na evolução tectônica da bacia (Milani \& Davison, 1988; Magnavita, 1992; Aragão \& Peraro, 1994; Magnavita et al., 1994; Peraro, 1995; Magnavita et al., 2012), ou na estratigrafia regional (Braun, 1966; Barreto, 1968; Magnavita \& Cupertino, 1987; Caixeta et al., 1994; Costa et al., 2007; Neumann et al., 2010, 2013; Neumann \& Rocha, 2014; Guzmán-González et al., 2015a, b, 2016; Varejão et al., 2016). De maneira a contribuir para o melhor entendimento desta formação, este trabalho enfoca análise faciológica e de sistemas deposicionais. Trata-se do primeiro trabalho em detalhe sobre fácies e sistemas deposicionais da Formação São Sebastião na Bacia do Jatobá.

\section{CONTEXTO GEOLÓGICO REGIONAL}

A Bacia de Jatobá situa-se nos estados de Pernambuco e da Bahia (Figura 1), principalmente na região conhecida como Sertão do Moxotó (Barbosa, 1964), compreendida pelas coordenadas $08^{\circ} 20^{\prime}$ a $09^{\circ} 10^{\prime}$ de latitude $\mathrm{S}$ e $37^{\circ} 00^{\prime}$ a $38^{\circ} 30^{\prime}$ de longitude $\mathrm{W}$, e ocupa uma área de aproximadamente $5.000 \mathrm{~km}^{2}$. O principal acesso faz-se através da BR 232, partindo do Recife até a cidade de Arcoverde, numa distância aproximada de $250 \mathrm{~km}$, onde já se observam as escarpas que limitam a área preservada da bacia (Rocha \& Leite, 1999) (Figura 1). A Bacia de Jatobá (Figura 2) faz parte do denominado Rifte Recôncavo-Tucano-Jatobá (RTJ), estrutura geotectônica constituída por extenso rifte abortado no Cretáceo durante as fases de fragmentação do Supercontinente Gondwana.

Os limites da bacia são a falha de Ibimirim, a norte, a falha de São Francisco, que a separa da subbacia de Tucano Norte, a oeste, e borda flexural, nas demais direções (Figura 3 ).

A bacia acha-se preenchida por sedimentos flúvio-deltaico-lacustrinos de idades do Paleozoico até o Neógeno, com destaque para aqueles depositados durante o Cretáceo Inferior. A estratigrafia admitida para a bacia inclui basicamente as mesmas unidades das bacias do Recôncavo e Tucano, entretanto a bacia apresenta importante seção do Paleozoico (Tabela 1).

Neste trabalho seguiu-se a coluna estratigráfica sugerida por Neumann et al. $(2010,2013)$ e Neumann \& Rocha (2014), na qual a Formação Santana de Rocha \& Leite (1999) foi elevada à categoria de Grupo Santana, representadas pelas Formações Crato e Romualdo (Tabela 1). 


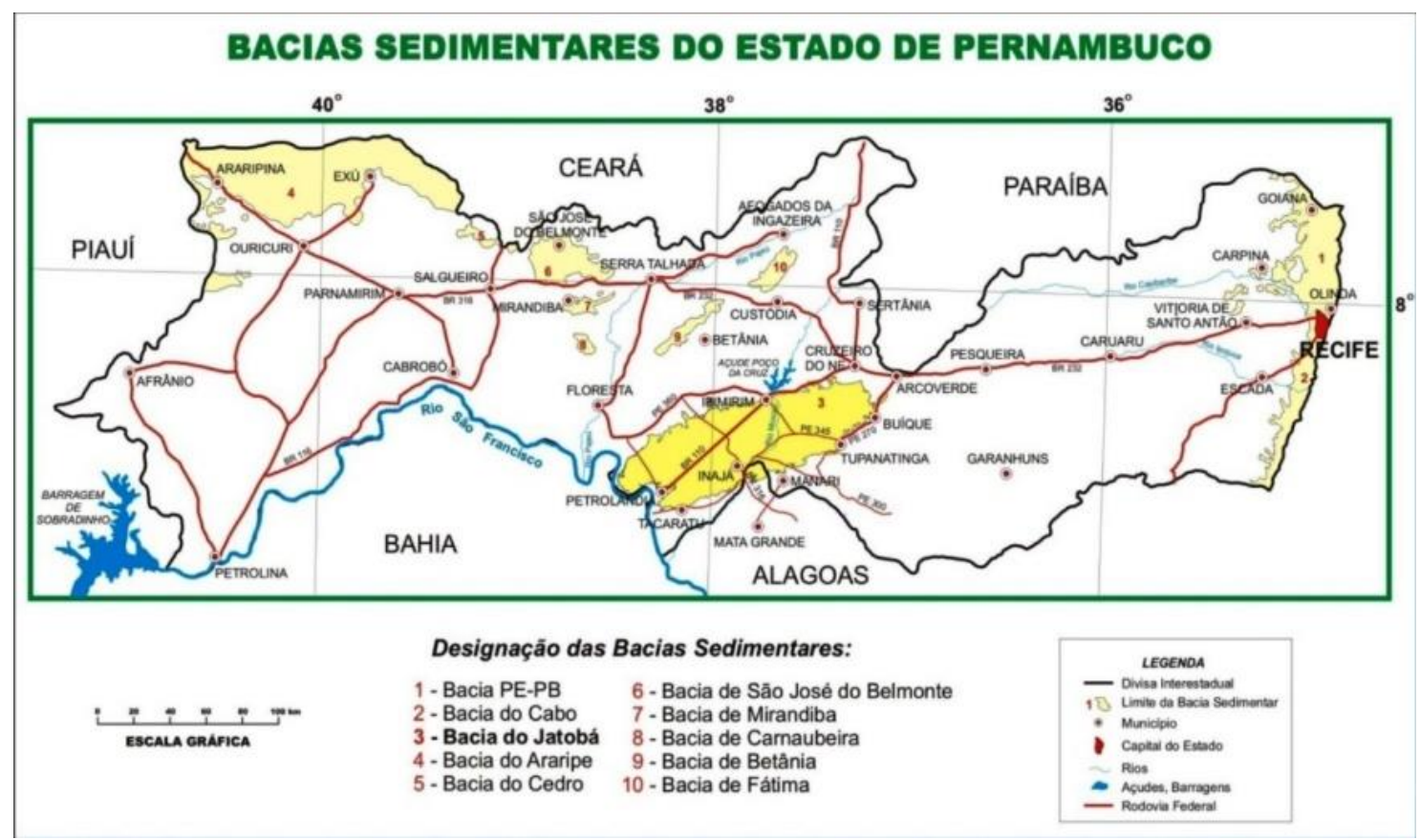

Figura 1 - Mapa de localização da Bacia do Jatobá, vias de acesso e principais sedes municipais (adaptada de Neumann et al., 2010).

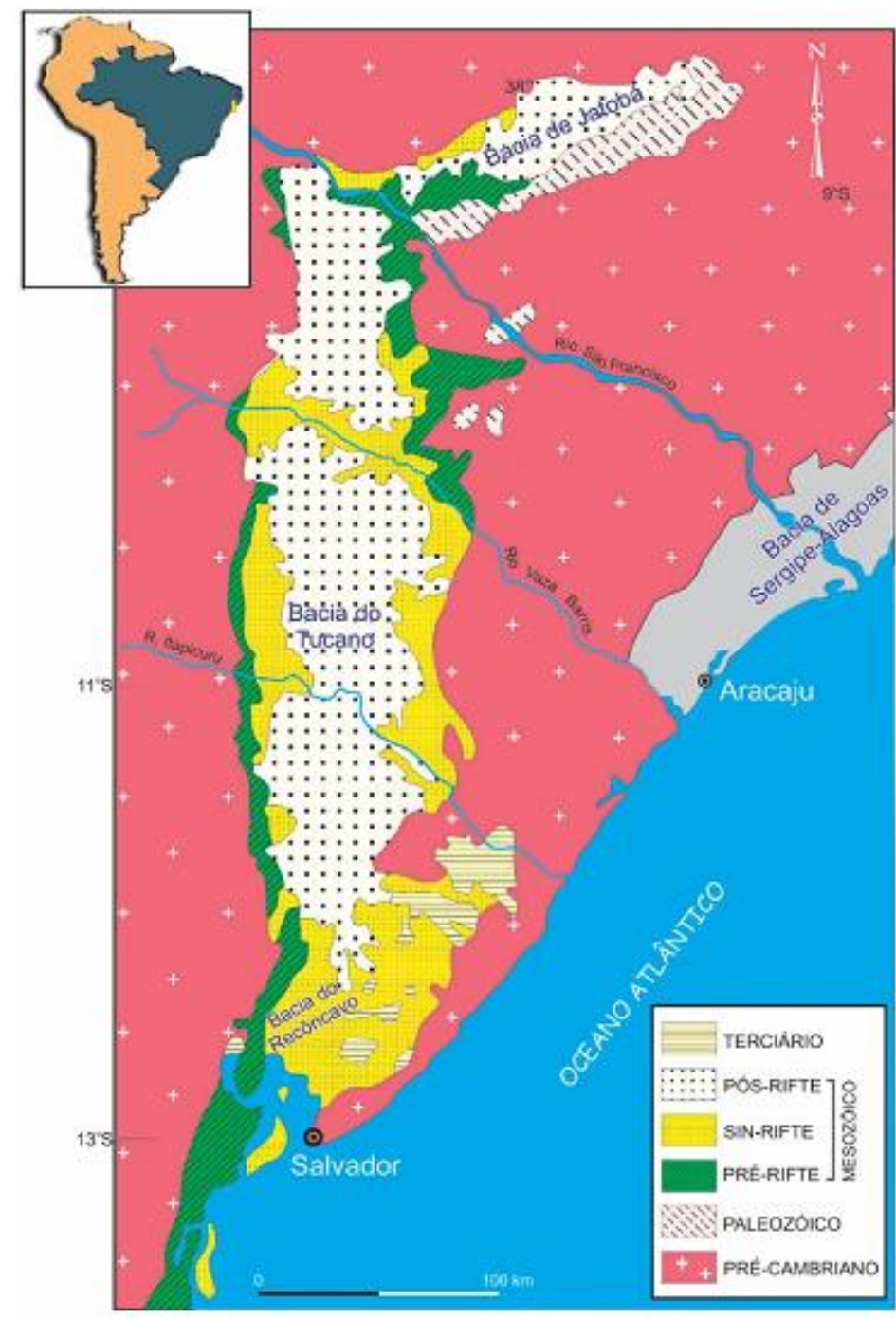

Figura 2 - Distribuição tectônica do Sistema Recôncavo-Tucano-Jatobá em rochas Pré-Rifte, Sin-Rifte e Pós-Rifte (modificada de Magnavita, 1992). 


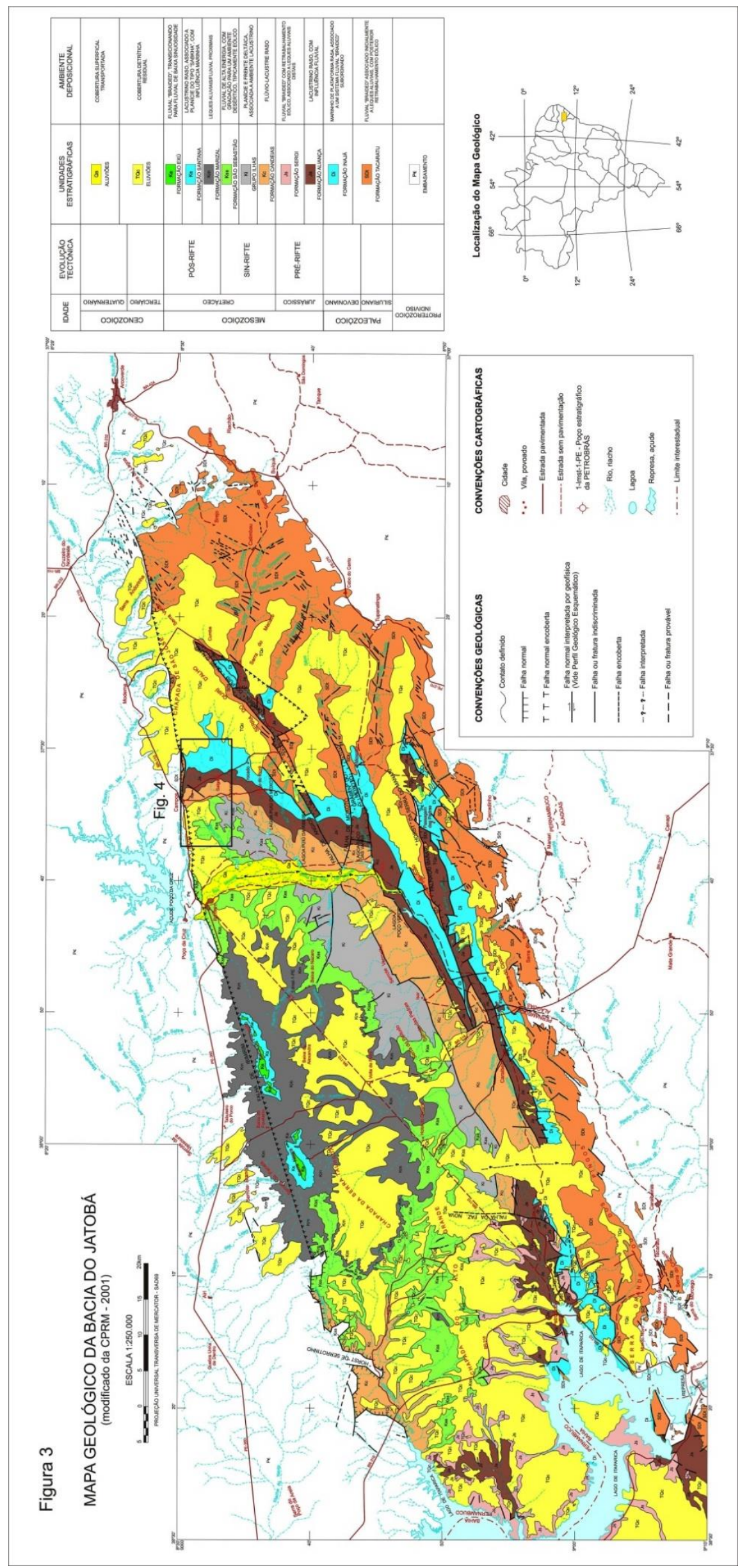

Figura 3 - Mapa geológico da Bacia do Jatobá. Modificado e simplificado a partir de Rocha \& Leite (2001). 
Tabela 1 - Coluna estratigráfica da Bacia do Jatobá. Modificada de Neumann et al. (2010, 2013) e de Carvalho et al. (2010), com base em Guzmán-González et al. (2015a).

\begin{tabular}{|c|c|c|c|c|c|c|}
\hline \multicolumn{3}{|c|}{ GEOCRONOLOGIA } & \multirow{2}{*}{\begin{tabular}{|l|} 
TECTÔ- \\
NICA \\
\end{tabular}} & \multirow{2}{*}{$\begin{array}{c}\text { UNIDADES } \\
\text { ESTRATIGRÁFICAS }\end{array}$} & \multirow{2}{*}{$\begin{array}{l}\text { AMBIENTE } \\
\text { DEPOSICIONAL }\end{array}$} & \multirow{2}{*}{ COMPOSIÇÃO LITOLÓGICA } \\
\hline ERA & PERIODO & IDADE & & & & \\
\hline \multirow{2}{*}{$\begin{array}{l}\text { O } \\
\text { : } \\
\text { Oे } \\
\text { O }\end{array}$} & Neógeno & $\begin{array}{l}\text { Pleisto- } \\
\text { ceno }\end{array}$ & & $\begin{array}{l}\text { Sedimentos } \\
\text { Aluvionares }\end{array}$ & Fluvial & $\begin{array}{l}\text { Areias, siltes, argilas e } \\
\text { lentes conglomeráticas }\end{array}$ \\
\hline & Paleógeno & $\begin{array}{l}\text { Oligo- } \\
\text { ceno }\end{array}$ & & $\begin{array}{l}\text { Depósitos } \\
\text { Colúvio-eluviais }\end{array}$ & $\begin{array}{l}\text { Cobertura detrítica } \\
\text { residual }\end{array}$ & Cascalhos e areias \\
\hline \multirow{10}{*}{ 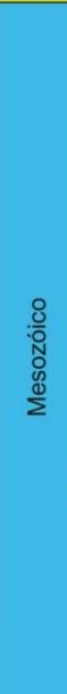 } & \multirow{8}{*}{ 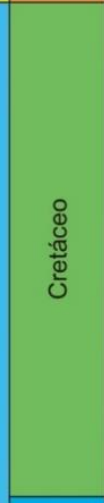 } & $\begin{array}{l}\text { Albiano/Ce- } \\
\text { nomaniano }\end{array}$ & $\begin{array}{l}\text { Pós- } \\
\text { Rifte II }\end{array}$ & Formação Exu & $\begin{array}{c}\text { Fluvial entrelaçado } \\
\text { e meandrante }\end{array}$ & $\begin{array}{l}\text { Arenitos grossos a conglomeráticos } \\
\text { com leitos finos }\end{array}$ \\
\hline & & \multirow{3}{*}{ Aptiano } & \multirow{3}{*}{$\begin{array}{l}\text { Pós- } \\
\text { Rifte I }\end{array}$} & Formação Romualdo & Lacustrino raso & $\begin{array}{l}\text { Siltitos e folhelhos na base e calcários } \\
\text { e calcário coquinóide no topo }\end{array}$ \\
\hline & & & & Formação Crato & $\begin{array}{l}\text { Lacustrino raso } \\
\text { a profundo }\end{array}$ & $\begin{array}{l}\text { Calcários laminados intercalados com } \\
\text { arenitos, margas, siltitos e folhelhos }\end{array}$ \\
\hline & & & & Formação Marizal & Fluvial de alta energia & $\begin{array}{l}\text { Arenitos grossos com estratificações } \\
\text { cruzadas, siltitos e argilitos }\end{array}$ \\
\hline & & $\begin{array}{l}\text { Barre- } \\
\text { miano }\end{array}$ & \multirow{4}{*}{$\begin{array}{c}\text { Climax } \\
\text { de } \\
\text { Rifte }\end{array}$} & Formacão & \multirow{2}{*}{$\begin{array}{l}\text { Fluvial de alta energia, } \\
\text { dunas e lençóis eólicos } \\
\text { e fluvial efêmero } \\
\text { intercalado nas eólicas }\end{array}$} & \multirow{2}{*}{$\begin{array}{l}\text { Arenitos médios a finos } \\
\text { com nives grossos na base }\end{array}$} \\
\hline & & $\begin{array}{l}\text { Haute- } \\
\text { riviano }\end{array}$ & & São Sebastião & & \\
\hline & & $\begin{array}{l}\text { Valan- } \\
\text { giniano }\end{array}$ & & $\begin{array}{l}\text { Grupo } \\
\text { Ilhas }\end{array}$ & $\begin{array}{l}\text { Deltaico associado } \\
\text { a lacustre }\end{array}$ & $\begin{array}{l}\text { Alternância de arenitos médios a grossos } \\
\text { com argilitos e siltitos creme }\end{array}$ \\
\hline & & $\begin{array}{l}\text { Berria- } \\
\text { siano }\end{array}$ & & $\begin{array}{l}\text { Formação } \\
\text { Candeias }\end{array}$ & $\begin{array}{l}\text { Flúvio-lacustre } \\
\text { raso }\end{array}$ & $\begin{array}{l}\text { Arenitos, folhelhos e siltitos argilosos } \\
\text { intercalados com carbonatos }\end{array}$ \\
\hline & \multirow{2}{*}{$\begin{array}{l}\frac{8}{5} \\
\frac{3}{\pi} \\
\frac{\pi}{3}\end{array}$} & \multirow{2}{*}{$\begin{array}{l}\text { Titho- } \\
\text { niano }\end{array}$} & \multirow{2}{*}{$\begin{array}{l}\text { Início } \\
\text { de } \\
\text { Rifte }\end{array}$} & $\begin{array}{l}\text { Formação } \\
\text { Sergi }\end{array}$ & $\begin{array}{l}\text { Fluvial entrelaçado } \\
\text { com retrabalhamento eólico }\end{array}$ & $\begin{array}{l}\text { Arenitos grossos a finos } \\
\text { com crosta laterítica }\end{array}$ \\
\hline & & & & $\begin{array}{l}\text { Formação } \\
\text { Aliança }\end{array}$ & $\begin{array}{l}\text { Lacustre raso } \\
\text { com influência fluvial }\end{array}$ & $\begin{array}{l}\text { Folhelhos e siltitos intercalados com } \\
\text { arenitos calciferos, calcáreos e gipsita }\end{array}$ \\
\hline \multirow{3}{*}{$\begin{array}{l}0 \\
: 0 \\
0 \\
0 \\
\frac{0}{0} \\
0\end{array}$} & \multirow{2}{*}{ 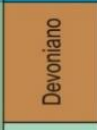 } & & \multirow{3}{*}{$\begin{array}{l}\text { Siné- } \\
\text { clise }\end{array}$} & $\begin{array}{l}\text { Formação } \\
\text { Inajá }\end{array}$ & $\begin{array}{l}\text { Marinho de plataforma } \\
\text { rasa associada } \\
\text { a fluvial }\end{array}$ & $\begin{array}{c}\text { Arenitos finos laminados e ferruginosos } \\
\text { com intercalaçöes de arenitos } \\
\text { grossos e siltitos }\end{array}$ \\
\hline & & & & & & \\
\hline & 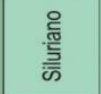 & & & $\begin{array}{l}\text { Formação } \\
\text { Tacaratu }\end{array}$ & $\begin{array}{l}\text { Fluvial entrelaçado } \\
\text { associado com } \\
\text { leques aluviais }\end{array}$ & $\begin{array}{l}\text { Arenitos grossos a conglomeráticos } \\
\text { com crostas lateríticas }\end{array}$ \\
\hline $\begin{array}{l}\text { Prote- } \\
\text { rozóico }\end{array}$ & & & & $\begin{array}{c}\text { Embasamento } \\
\text { Cristalino }\end{array}$ & & $\begin{array}{c}\text { Granitos, migmatitos, gnaisses, } \\
\text { sienogranitos, monzogranito } \\
\text { e quartzitos }\end{array}$ \\
\hline
\end{tabular}

A Bacia de Jatobá foi subdividida nas tectonossequências Beta, Pré-Rifte, Rifte, PósRifte e Zeta por Rocha \& Amaral (2007) com base na correlação estratigráfica com a Bacia do Araripe. No entanto, o empilhamento sedimentar da bacia adotado seguiu a proposta de Fambrini et al. (2011) para a Bacia do Araripe e subdividido por Guzmán-González et al. (2015a) em: a) Sequência Sinéclise (Grupo Jatobá), representada pelas formações Tacaratu e Inajá; b) Sequência de Início de Rifte (Grupo Brotas), representada pelas formações Aliança e Sergi; c) Sequência de Clímax de Rifte representada pelas formações Candeias e São Sebastião e Grupo Ilhas; d) Sequência PósRifte, representada pela Formação Marizal, pelo Grupo Santana e pela Formação Exu (Tabela 1).

A Sequência Sinéclise é composta pelas formações Tacaratu e Inajá (Grupo Jatobá), e foi posicionada no Siluro-Devoniano (Braun, 1966; Barreto, 1968), podendo ser mais antiga (Carvalho et al., 2018). A primeira compreende camadas de arenitos grossos e conglomerados depositados preferencialmente em sistemas continentais (leques aluviais que gradam para sistemas fluviais entrelaçados (Carvalho et al., 2010). Já a Formação Inajá apresenta sedimentos da ingressão marinha que marcou o Devoniano do território brasileiro. Compreendem siltitos, folhelhos e arenitos finos a médios com evidências de atuação de ondas normais e de tempestade, e inclui fósseis de fauna marinha.

A Sequência de Início de Rifte (Grupo Brotas) abrange as formações Aliança e Sergi, situadas no intervalo Neojurássico-Eocretaceo (Fambrini et al., 2016). A Formação Aliança abarca sedimentos predominantemente pelíticos (argilitos e folhelhos vermelho-amarronzados), com delgadas camadas de calcários e arenitos calcíferos abundantemente fossilíferos. Os gêneros encontrados referem-se a ostracodes (Theriosynoecum, Reconcavona e Alicenula) que mostram afinidade com águas doces e habitavam corpos de água permanentes, como lagos (Guzmán-González, 2015; GuzmánGonzález et al., 2015a, 2015b, 2016). A Formação Sergi inclui arenitos médios a finos bem selecionados de ambiente eólico, e arenitos grossos 
a médios, localmente conglomeráticos, relacionados a sistemas fluviais efêmeros. A unidade apresenta abundantes lenhos fósseis de coníferas.

A Sequência de Clímax de Rifte envolve as unidades Formação Candeias, Grupo Ilhas e Formação São Sebastião. A Formação Candeias é constituída por pelitos representantes de fase lacustre com elevada taxa de subsidência, associados a arenitos delgados correspondentes a sistemas de leques deltaicos. A redução na taxa de subsidência inicial, indicada por calcários oncolíticos no topo da Formação Candeias possibilitou a progradação de sistemas deltaicos sobre plataformas existentes próximo às bordas flexurais da bacia, possibilitando o preenchimento do depocentro com arenitos, siltitos e, subordinadamente, folhelhos e poucos carbonatos do Grupo Ilhas. Em termos paleontológicos, a Formação Candeias na região de Campos-Ibimirim apresenta microfósseis de vertebrados representados por dentes isolados e escamas de peixes ósseos, identificadas como cf. Lepidotes e Actinopterygii indeterminados, além de numerosos dentes faringianos identificados como Stephanodus, um táxon parafilético de peixes ósseos (Silva et al., 2015). Ostracodes associados incluem Cypridea e Reconcavona (Viana, 1966), cujas ocorrências estratigraficamente inferiores sugerem uma idade Rio da Serra/Aratu para a Sequência de Climas de Rifte na Bacia do Jatobá (Silva et al., 2015).

A Formação São Sebastião é composta na base, por arenitos avermelhados, com incomuns níveis grossos na base, variando de arenitos grossos a finos, de seleção regular, por vezes oxidados, e em direção ao topo a unidade acha-se caracterizada por arenitos róseo-avermelhados com manchas de coloração creme, de granulação variando de fina a muito fina, bem selecionados, bimodais, dispostos em estratos bandados, de aspecto rítmico, devido à pigmentação ferruginosa em alguns estratos, nos quais são corriqueiras as estratificações cruzadas acanaladas de grande porte com padrão de paleocorrentes indicando diversos sentidos do fluxo sedimentar (Rocha, 2011; Fambrini et al., 2013; Guzmán-González et al., 2015a).

A Sequência Pós-Rifte acha-se representada pelas formações Marizal, Crato, Romualdo e Exu, de acordo com Neumann et al. (2010, 2013) e Neumann \& Rocha (2014). Em recente revisão da estratigrafia da Bacia de Jatobá, Guzmán-González et al. (2015a) incluíram as unidades Crato, Romualdo e Exu, desmembrando-as da Formação Marizal, como sugerido previamente por Caixeta et al. (1994) e por Costa et al. (2007). Segundo Rocha (2011), a Formação Marizal na Bacia de Jatobá, é constituída essencialmente por arenitos esbranquiçados de granulação variando de média a grossa, por vezes fina, associados de forma subordinada, a siltitos e argilitos. Ademais desta litologia destacam-se arenitos conglomeráticos com estruturas do tipo estratificações cruzadas acanaladas de pequeno a médio porte e estruturas de sobrecarga e fluidificação (Costa et al., 2007).

Por fim, coberturas de idade cenozoica estão englobadas na tectosequência Zeta (Neumann et al., 2010). Neste conjunto predominam coberturas detríticas residuais representadas por sedimentos elúvio/coluviais, de caráter essencialmente arenoso, com rara contribuição pelítica. Estes sedimentos ocupam faixas bastante significativas e formam extensos areais, e se distribuem por extensas áreas irregulares em toda a bacia, provenientes do retrabalhamento dos sedimentos arenosos das formações Tacaratu, Sergi, Candeias, São Sebastião e Marizal (Rocha \& Amaral, 2007; Rocha, 2011).

\section{MATERIAIS E MÉTODOS DE TRABALHO}

Os métodos adotados para este trabalho incluem o seguinte esquema:

(i) análise estratigráfica de fácies por meio do levantamento de seções colunares medidas e estabelecimento de litofácies; (ii) identificação e descrição das estruturas sedimentares presentes; (iii) análise de sistemas deposicionais; (iv) coleta de medidas de paleocorrentes; (v) tratamento dos dados em gabinete.

As fácies foram identificadas segundo a litologia predominante, geometria dos corpos, estruturas sedimentares e padrão de paleocorrentes conforme trabalhos de Miall (1978, 1996) e Walker (1992, 2006). Foi elaborado esquema de litofácies a partir de Miall (1978, 1996). As estruturas sedimentares foram identificadas e descritas com base em Collinson \& Thompson (1989) e Selley (2000). Os sistemas deposicionais tiveram como base os trabalhos de Walker \& James (1992), Schanley \& McCabe (1994), Reading (1996) e James \& Dalrymple (2010). Na análise dos sistemas fluviais, os trabalhos de Jones et al. (2001), Miall (1996, 2000), Scherer et al. (2007), Le Heron et al. 
(2008), entre outros, foram considerados. Já na análise dos sistemas eólicos, trabalhos de Brookfield (1977), Kocurek \& Dott (1981), Kocurek (1996), Scherer \& Lavina (2005), Mountney (2006), LeTourneau \& Huber (2006), Paim \& Scherer (2007), Dias \& Scherer (2008), Spaletti et al. (2010) e Jones et al. (2016) foram utilizados. A análise de paleocorrentes baseou-se na medição sistemática de estruturas sedimentares indicadoras de paleofluxo, tais como estratificações cruzadas acanaladas e tabulares, de acordo com trabalhos de Miall (1981, 1985, 1996, 2000), Potter \& Pettijohn (1977) e Assine (1994). Foram tomadas medidas nos estratos frontais destas estratificações sempre com visualização tridimensional (3D).

\section{FORMAÇÃO SÃO SEBASTIÃO}

A Formação São Sebastião, que é parte integrante do Grupo Massacará do Supergrupo Bahia, neste trabalho foi considerada como unidade indivisa, embora, nas bacias de Tucano e do Recôncavo tenha sido subdividida nos membros Paciência, Passagem dos Teixeiras e Rio Joanes, de acordo com Viana et al. (1971). $\mathrm{Na}$ área estudada na Bacia de Jatobá a formação possui representatividade bastante restrita, pois a maior parte de seus afloramentos está distribuída ao longo de uma faixa NE-SW, fora da citada área (Figuras 3 e 4) cuja espessura medida resultou em apenas $110 \mathrm{~m}$.

De forma geral as exposições da Formação São Sebastião na Bacia de Jatobá constituem serras arredondadas ou morrotes ondulados e, mais raramente, serras escarpadas (Figura 5).

As principais exposições desta unidade situam-se na região de Campos, na Fazenda Paraíso e sua principal característica fotogeológica é a textura rugosa esbranquiçada (Rocha \& Leite, 2001).
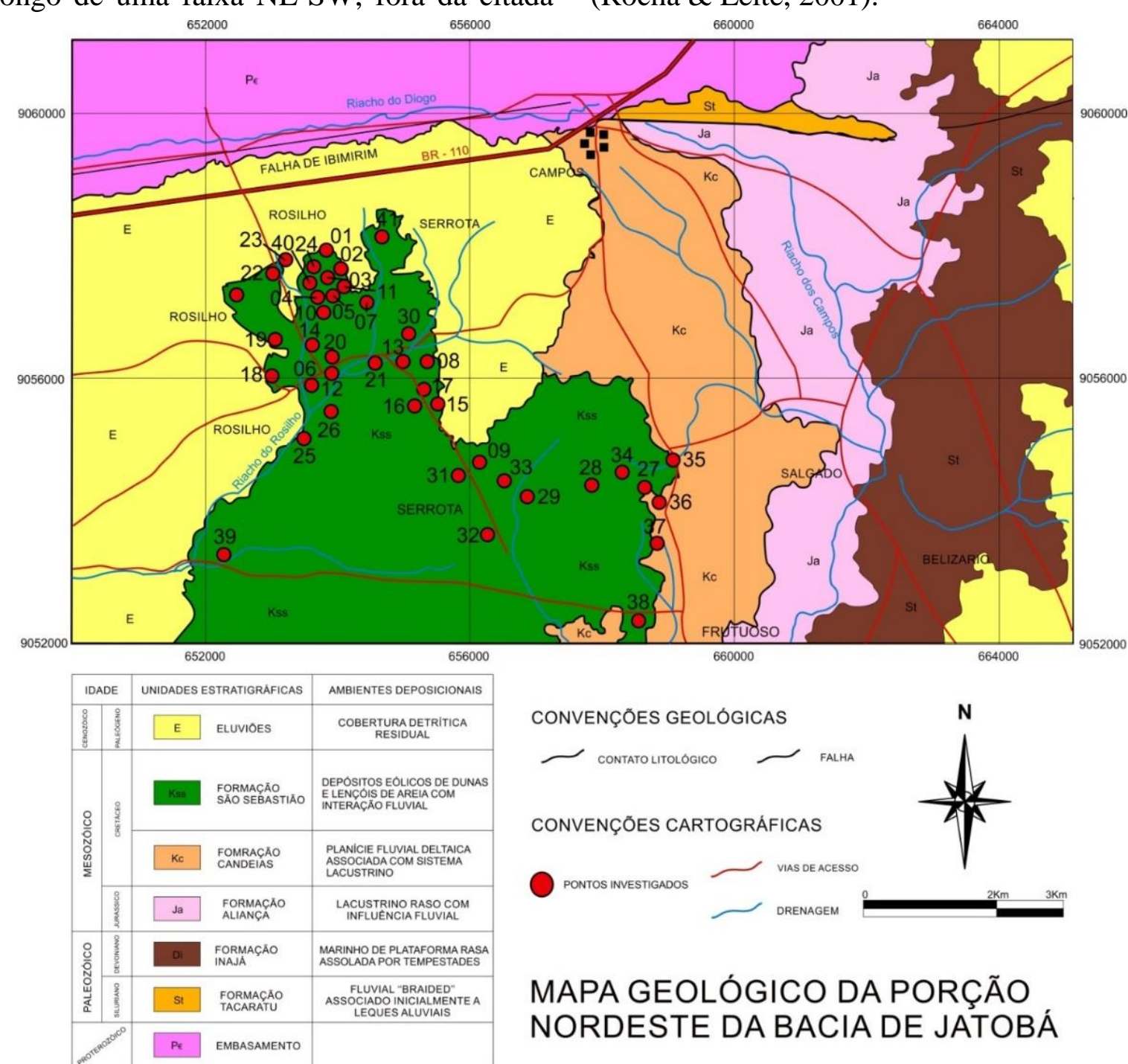

\section{MAPA GEOLÓGICO DA PORÇÃO NORDESTE DA BACIA DE JATOBÁ}

Figura 4 - Mapa geológico da Bacia do Jatobá na região de Ibimirim-Campos. Modificada de Fambrini et al. (2006, 2007). 

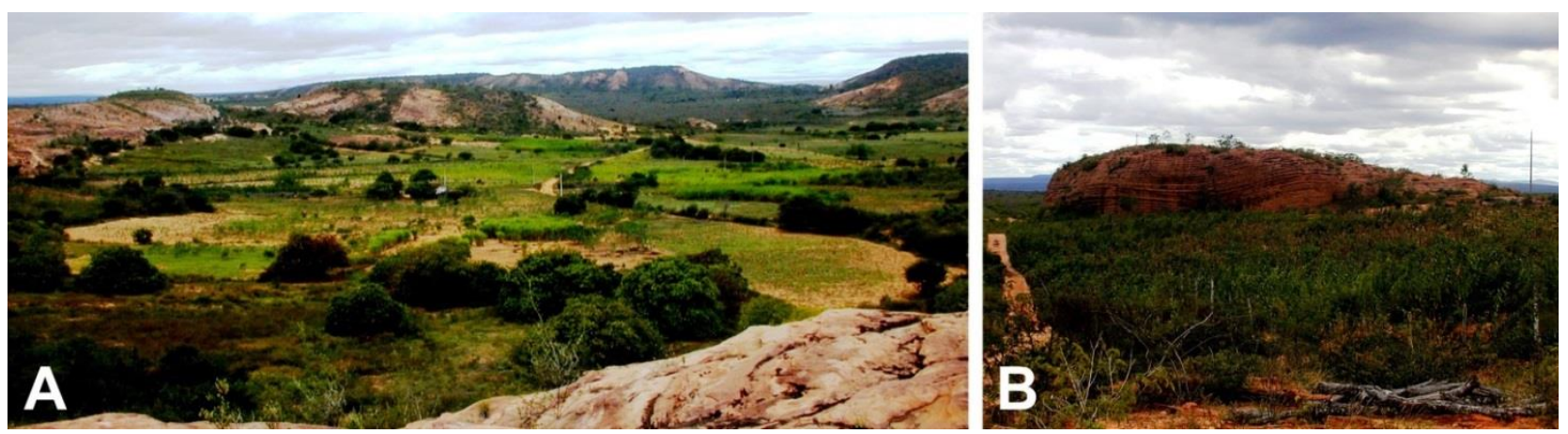

Figura 5 - Os afloramentos da Formação São Sebastião constituem serras arredondadas ou morrotes ondulados A) vista a partir do ponto 05, e, mais raramente, serras escarpadas $\mathbf{B}$ ) ponto 14.

A base da sucessão, que se assenta diretamente sobre folhelhos da Formação Candeias por contato erosivo (Figura 6) é composta por arenitos grossos a médios, localmente conglomeráticos, mal selecionados, com estratificações cruzadas tabulares e acanaladas, interpretados como originados por sistema fluvial entrelaçado de alta energia. Para o topo, bem exposto na área investigada, sobressaem-se arenitos finos a muito finos (bimodais), róseo-avermelhados com manchas de coloração creme, bem selecionados, dispostos em estratos bandados, de aspecto rítmico, devido à pigmentação ferruginosa em alguns estratos (sets).

Esses arenitos são interpretados como formados por sistema eólico em ambiente possivelmente desértico.

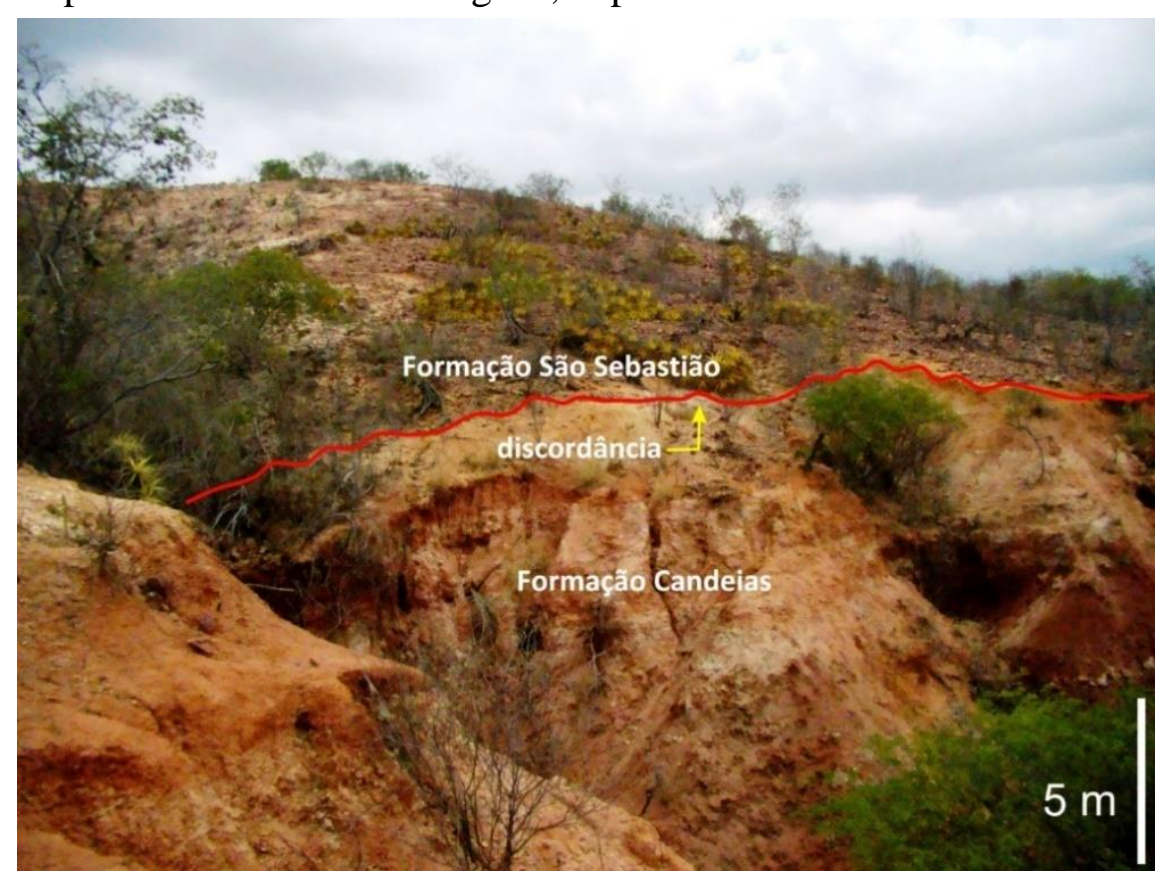

Figura 6 - Contato por discordância erosiva entre as formações Candeias e São Sebastião. Pontos 27 e 28.

Litologicamente, a formação está bimodais, de coloração rósea avermelhada a caracterizada por arenitos médios a finos, com poucos níveis grossos na base, gradando para arenitos finos a muito finos (bimodais), em direção ao topo.

Os arenitos basais possuem coloração predominantemente avermelhada, grãos subarredondados, seleção regular a pobre, e muitas vezes formam estratos bandados com aspecto rítmico em função da pigmentação ferruginosa presente em alguns estratos. A sequência de topo está caracterizada por arenitos creme, bem selecionados, formados por grãos de quartzo subarredondados a arredondados, apresentando níveis um pouco mais grossos, que caracterizam fluxo de grão (grain flow).

Em termos estratigráficos, a Formação São Sebastião foi dividida em três conjuntos. A base da formação é constituída pela interdigitação de camadas tabulares de origem eólica e fluvial normalmente separadas por superfícies planas horizontais de grande continuidade lateral. O destaque desse conjunto é o estabelecimento de 
grande campo de dunas e lençóis de areia eólicos e períodos de estação seca, ambos comumente apresentando estruturas de deformação em sedimentos inconsolidados, ao passo que em períodos mais úmidos passaram a predominar sistemas fluviais entrelaçados desconfinados. A porção central é caracterizada por lençóis de areia do tipo zibar, canais fluviais efêmeros e dunas eólicas, apresentando interdigitação tanto lateral quanto vertical. A ocorrência de zibars e dunas eólicas indica a alta intensidade dos ventos que sopravam nesse período. Por fim, a porção superior retoma as condições secas com mudança climática e deposicional materializada por uma superfície plana de grande continuidade lateral.

Esse conjunto caracteriza-se pela disponibilidade de areia seca e favorável à formação de grande campo de dunas eólicas, com o aparecimento de dunas compostas, simultâneas com as dunas simples.

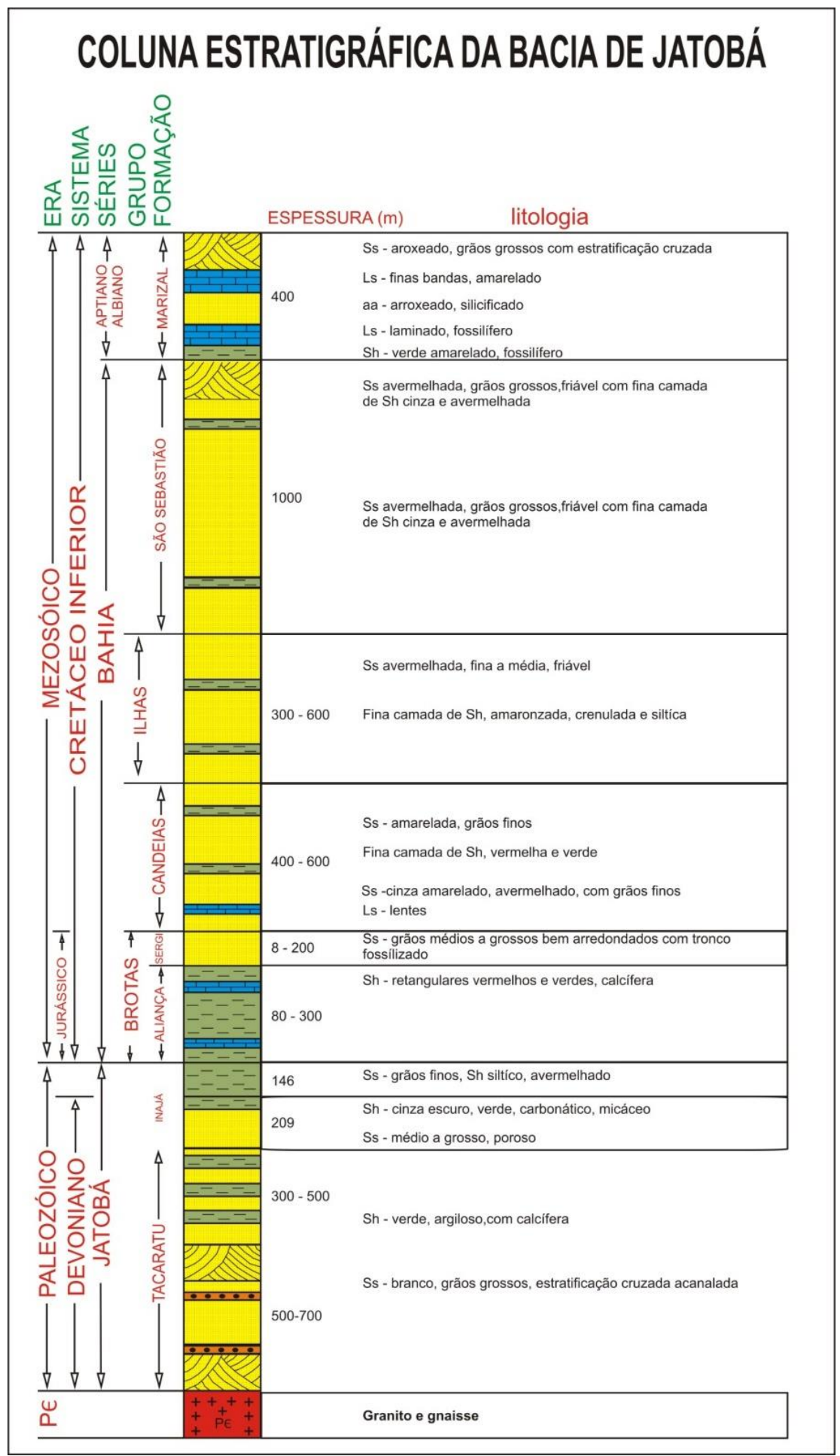

Figura 7 - Coluna litoestratigráfica da Bacia do Jatobá. Elaborada a partir do Poço 2-IMst-1-PE. Modificada de Fonseca (1966). Vide localização na figura 3. 


\section{Análise Faciológica da Formação São Sebastião}

A análise faciológica implementada para a Formação São Sebastião permitiu a separação em onze litofácies principais (Tabela 2).
As litofácies incluem arenitos variados, a principal litologia, e conglomerados subordinados. As fácies distinguidas estão sumarizadas na tabela 2 e estão descritas pormenorizadamente a seguir.

Tabela 2 - Litofácies encontradas na Formação São Sebastião. Código de litofácies a partir de Miall (1977, 1978, 1996).

\begin{tabular}{|c|c|c|}
\hline Código & Descrição da Litofácies & Interpretação \\
\hline Gm & $\begin{array}{l}\text { Conglomerados sustentados pela matriz, maciços, de } \\
\text { grânulos a seixos pequenos, clastos subarredondados a } \\
\text { arredondados, mal selecionados. Camadas tabulares ou } \\
\text { lenticulares com } 10 \text { a } 30 \mathrm{~cm} \text { de espessura, na maioria das } \\
\text { vezes na base dos ciclos de gradação normal. }\end{array}$ & $\begin{array}{l}\text { Processo deposicional foi interpretado como } \\
\text { decorrente de fluxo hidrodinâmico } \\
\text { unidirecional trativo de alta energia associado } \\
\text { à erosão intraformacional predominante. } \\
\text { Depósitos residuais (lags). }\end{array}$ \\
\hline Scg & $\begin{array}{l}\text { Arenitos grossos a médios, conglomeráticos de grânulos } \\
\text { e pequenos seixos, mal selecionados, com estratificação } \\
\text { plano-paralela e estratificações cruzadas acanaladas de } \\
\text { pequeno porte. }\end{array}$ & $\begin{array}{l}\text { Depósitos de correntes aquosas em barras } \\
\text { longitudinais fluviais. Alta energia. }\end{array}$ \\
\hline$S t$ & $\begin{array}{l}\text { Arenito fino a médio ou grosso a muito grosso, por vezes } \\
\text { seixoso, com estratificações cruzadas acanaladas de } \\
\text { porte pequeno a médio, solitárias ou agrupadas. }\end{array}$ & $\begin{array}{l}\text { Meso ou macroformas de leito (Dunas 3D) } \\
\text { depositadas por tração subaquosa, relacionadas } \\
\text { às barras fluviais de crista sinuosa ou } \\
\text { linguóides. }\end{array}$ \\
\hline Sh & $\begin{array}{l}\text { Arenitos (areia muito fina a muito grossa, podendo } \\
\text { conter seixos dependendo da fácies), com laminação e } \\
\text { estratificação plano paralela. }\end{array}$ & $\begin{array}{l}\text { Leito plano depositado por tração subaquosa } \\
\text { sob regime de fluxo superior. Relaciona-se a } \\
\text { depósitos de planície de inundação e topo de } \\
\text { barras fluviais. }\end{array}$ \\
\hline$S p$ & $\begin{array}{l}\text { Arenitos médios a muito grossos, por vezes com seixos } \\
\text { com estratificações cruzadas tabulares de pequeno e } \\
\text { médio porte. }\end{array}$ & $\begin{array}{l}\text { Dunas arenosas tridimensionais (3D) } \\
\text { subaquáticas formadas sob regime de fluxo } \\
\text { inferior. }\end{array}$ \\
\hline$S m$ & $\begin{array}{l}\text { Arenito fino a muito grosso, maciço. Pode conter } \\
\text { intraclastos de argila. }\end{array}$ & $\begin{array}{l}\text { Fluxo hiperconcentrado durante inundação. O } \\
\text { caráter maciço também pode ser função de } \\
\text { alterações pós-deposicionais, como } \\
\text { bioturbação ou variações no lençol freático. }\end{array}$ \\
\hline $\begin{array}{l}\text { Stbm } \\
\text { (eólica) }\end{array}$ & $\begin{array}{l}\text { Arenito médio a grosso, bimodal, bem selecionado por } \\
\text { nível, com estratificação cruzada acanalada de porte } \\
\text { médio a muito grande, com } 1 \text { a } 7 \mathrm{~m} \text { de espessura, } \\
\text { compostos por depósitos de fluxo de grão e por } \\
\text { laminações de marcas onduladas eólicas. }\end{array}$ & $\begin{array}{l}\text { Processos de fluxo e queda de grãos } \\
\text { desenvolvidos na face de sotavento de } \\
\text { depósitos de dunas eólicas. }\end{array}$ \\
\hline $\begin{array}{c}\text { Sp } \\
\text { (eólica) }\end{array}$ & $\begin{array}{l}\text { Arenitos finos a médios, bem a moderadamente } \\
\text { selecionados, dispostos em sets de estratificação } \\
\text { cruzada tabular, com laminações pinstripe. }\end{array}$ & $\begin{array}{l}\text { Processos sedimentares que refletem fluxo } \\
\text { transversal do vento e, portanto, dunas de crista } \\
\text { reta (2D). }\end{array}$ \\
\hline$S d$ & $\begin{array}{l}\text { Arenito fino a médio, bimodal, com laminações e dobras } \\
\text { convolutas (camada desorganizada), contorcidas. }\end{array}$ & $\begin{array}{l}\text { Deformação sinsedimentar de estratos causada } \\
\text { por mudanças na poro-pressão dos sedimentos } \\
\text { geradas pela variação do nível do lençol } \\
\text { freático. }\end{array}$ \\
\hline $\begin{array}{c}S l \\
\text { (eólica) }\end{array}$ & $\begin{array}{l}\text { Arenitos finos a médios, laminados, muito bem } \\
\text { selecionados, dispostos em estratos com estratificação } \\
\text { cruzada de baixo ângulo com espessuras de } 40 \mathrm{~cm} \text { até } \\
3,5 \text { m. Os estratos cruzados são compostos por } \\
\text { laminações de marcas onduladas eólicas. }\end{array}$ & $\begin{array}{l}\text { Saltação e arraste de grãos em condições } \\
\text { subaéreas, originando lâminas plano-paralelas } \\
\text { ou de baixo ângulo (ondulação transladante). } \\
\text { Constituem depósitos de interdunas ou de } \\
\text { lençóis de areia. }\end{array}$ \\
\hline $\begin{array}{c}\text { Sh } \\
\text { (eólica) }\end{array}$ & $\begin{array}{l}\text { Arenitos finos a médios muito bem selecionados, } \\
\text { dispostos em camadas tabulares com estratificação } \\
\text { plano-paralela de } 20 \text { a } 40 \mathrm{~cm} \text { de espessura. }\end{array}$ & $\begin{array}{l}\text { Representam depósitos de interduna ou de } \\
\text { lençóis de areia. }\end{array}$ \\
\hline
\end{tabular}

Fácies de Conglomerados Maciços (fácies Gm)

Esta litofácies consiste de conglomerados sustentados pelo arcabouço, maciços, de grânulos a seixos pequenos (até $6 \mathrm{~cm}$ ) subarredondados a arredondados, por vezes calhaus, com fragmentos de quartzo branco leitoso, quartzo cinza, siltitos, mal selecionados (Figuras 8A, B). As camadas são tabulares ou lenticulares com 10 a $30 \mathrm{~cm}$ de espessura, e ocorrem na maioria das vezes na base dos ciclos de gradação normal. No contato geológico com a Formação Candeias há camada mais espessa de 
conglomerados e arenitos conglomeráticos associados, que superam 1 metro de espessura. $\mathrm{O}$ processo deposicional foi interpretado como decorrente de fluxo hidrodinâmico unidirecional trativo de alta energia associado à erosão intraformacional. Correlaciona-se à fácies $\mathrm{Gcm}$ de Miall (1996), correspondentes a depósitos residuais de canal (lags).
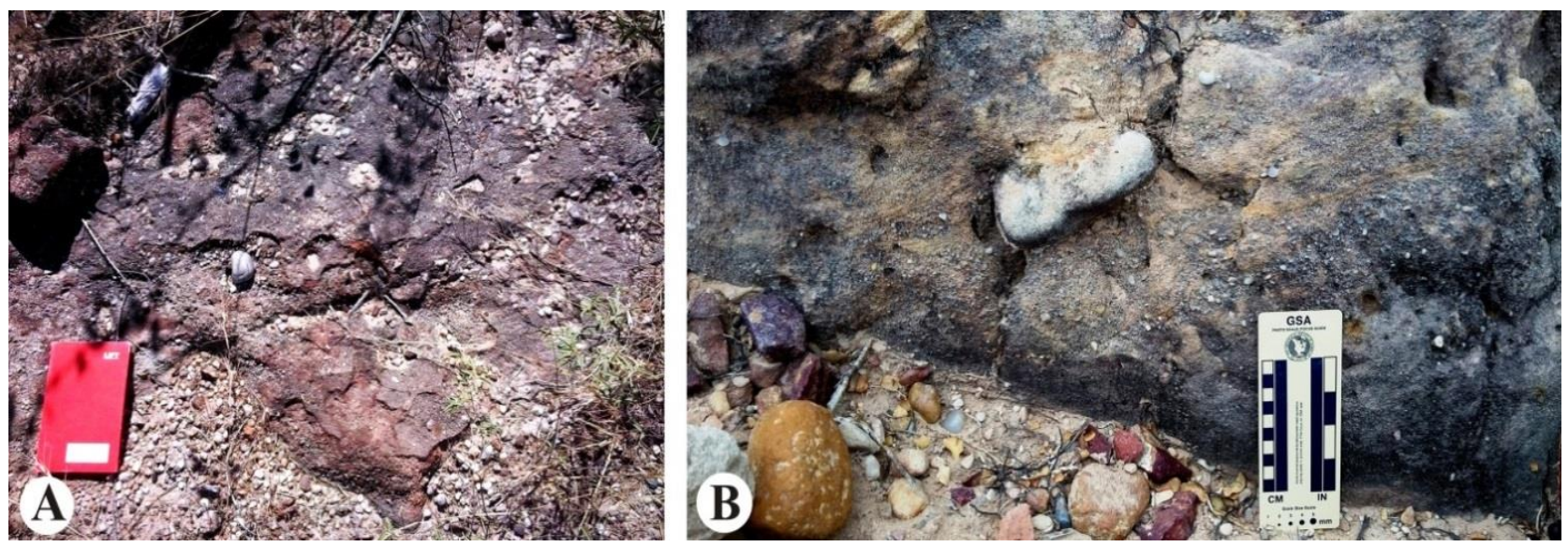

Figura 8 - Litofácies fluviais identificadas e descritas na Formação São Sebastião na região de Campos-Ibimirim. Região de contato com a subjacente Formação Candeias. A) litofácies Scg de arenitos grossos a médios, conglomeráticos de grânulos e pequenos seixos, mal selecionados, coloração róseo-avermelhada, maciços, B) litofácies Gm Conglomerados sustentados pelos clastos, maciços a pouco orientados. Ponto 27.

Fácies de Arenitos Conglomeráticos Estratificados (fácies $S c g$ )

Esta litofácies compõe-se de arenitos grossos a médios, conglomeráticos de grânulos e pequenos seixos, mal selecionados, coloração róseo-avermelhada, estratificados. Os clastos são predominantemente constituídos por grânulos e seixos de até $6 \mathrm{~cm}$, notadamente de quartzo leitoso, quartzo cinza, siltitos e feldspato róseo. As camadas apresentam geometria lenticular com espessuras que normalmente variam entre 20 e $50 \mathrm{~cm}$ (Figuras 9A, B, C, E). As estruturas sedimentares presentes são estratificação planoparalela e estratificações cruzadas acanaladas de pequeno porte com espessuras que normalmente variam entre 20 e $40 \mathrm{~cm}$. Esta litofácies subordina-se às litofácies St e Sp, abaixo discutidas. A litofácies de Arenitos Conglomeráticos Estratificados (Litofácies Scg) é interpretada como depósitos de correntes aquosas em barras longitudinais fluviais segundo os preceitos de Miall $(1977,1996)$.

Fácies de Arenitos com Estratificação Cruzada Acanalada (fácies St)

A litofácies St é composta de arenitos finos a grossos, por vezes com seixos e grânulos, mal selecionados, dispostos em camadas com estratificações cruzadas acanaladas de médio e pequeno porte com 0,1 até $1 \mathrm{~m}$ de espessura, com gradação normal (Figuras 9A, B e C). Os arenitos são de coloração vermelho-alaranjado a róseoavermelhado. Esta fácies é normalmente interpretada como produto de migração de formas de leito tridimensionais (dunas e barras 3D) geradas por depósitos de dunas subaquáticas de cristas sinuosas ou linguóides em regime de fluxo inferior em canais fluviais entrelaçados de alta energia (Miall, 1977, 1981, 1996; Hjellbakk, 1997; Miall, 2014).

Fácies de Arenitos com Estratificação PlanoParalela (fácies Sh)

Esta litofácies é formada de arenitos médios a finos com seixos esparsos, bem estratificados, mal selecionados, dispostos em camadas decimétricas $(30-75 \mathrm{~cm})$ de geometria tabular de grande persistência lateral, com estratificação plano-paralela bem conspícua (Figuras 9B, E, F, H). Esta litofácies foi interpretada como depósitos de correntes em regime de fluxo superior, associada a diversos processos de acordo com a associação de fácies em que se encontra. Representam depósitos de fluxo laminar superior em barras transversais ou linguóides de sistemas fluviais de rios entrelaçados. Podem representar também sand waves.

\section{Fácies de Arenitos com Estratificação Cruzada Tabular (fácies $S p$ )}

Esta litofácies é constituída por arenitos finos a médios, feldspáticos, com seleção regular a boa, de coloração castanha a rosada, com estratificação cruzada tabular de médio ângulo, em camadas de pequeno e médio porte (Figura 9F) de geometria lenticular. Esta litofácies foi 
interpretada como depósitos de migração de barras longitudinais de correntes fluviais de canais entrelaçados de acordo com os preceitos de Miall (1977, 1981, 1996).

Fácies de Arenitos Maciços (fácies Sm)

A litofácies Sm é formada por arenitos finos a muito grossos, maciços, de espessura em geral centimétrica, por vezes decimétrica (Figura 9D). Os arenitos podem conter intraclastos de argila. Os arenitos maciços são geralmente interpretados como depósitos de fluxo gravitacional granular originados por processos de fluxo hiperconcentrado durante inundação fluvial. Porém, a presença ocasional de níveis retorcidos sugere a possibilidade de alguns arenitos maciços serem o resultado de liquefação de arenitos estruturados, com consequente homogeneização granulométrica e obliteração de estruturas primária por deformação pene contemporânea tornando maciça a fácies.

Fácies de Arenitos com Estratificação Cruzada Acanalada de grande porte (fácies St $t_{b m}$ eólica)

Trata-se da principal litofácies da área investigada, pois ocorre em todos os intervalos estratigráficos. Esta litofácies é composta por arenitos médios a finos com estratificação cruzada acanalada de grande porte (Figura 10), caracterizada por laminação risca de agulha (pinstripe) conspícua (Figuras 11A, C, D, E, F, $\mathrm{G})$, em séries que alternam espessura de decímetros até mais de $20 \mathrm{~m}$ e apresentam grande continuidade lateral, podendo atingir de duas a quatro dezenas de metros (Figuras 10, 11A, C, D, F, G).

Os arenitos são bem selecionados por estrato, possuem bimodalidade e bom arredondamento (Figuras 11B, J). Os contatos reconhecidos entre as séries e conjunto de séries são de três tipos: superfície de reativação, superfície de superimposição e superfície de migração de interduna, conforme descrito por Mountney (2006). Pelas características descritas acima, interpretou-se que a fácies $\mathrm{St}_{\mathrm{bm}}$ representa depósitos de dunas eólicas barcanoides (sensu Hunter, 1977b; Kocurek, 1996; Mountney, 2006).

Fácies de Arenitos com Estratificação Cruzada Tabular e laminação pinstripe (fácies Sp eólica) Spbm

Arenitos finos a médios, bem a moderadamente selecionados, dispostos em sets de estratificação cruzada tabular, com espessura entre $50 \mathrm{~cm}$ e $1,5 \mathrm{~m}$ de espessura e aproximadamente $8 \mathrm{~m}$ de comprimento, com laminações conspícuas fruto da alternância de lâminas bem selecionadas de grãos finos e de grãos grossos, denominadas de laminação risca de agulha (pinstripe lamination) (Figuras 10C, E) (sensu Hunter, 1977a, b; Fryberger \& Schenk, 1988). Para esta fácies processos de deposição eólica com predominância de saltação e suspensão sob regime de vento variável unidirecional e migração de ondas sob regime subcrítico foram interpretadas, resultando em deposição de dunas eólicas bidimensionais (2D). Fácies de Arenitos com Estratificação PlanoParalela e laminação pinstripe (fácies $S h_{p s}$ eólica)

Esta litofácies compreende delgados níveis recorrentes de arenitos finos a muito finos, sílticos, tabulares, bem estratificados, caracterizados por laminação risca de agulha (pinstripe) bem conspícua (Figuras 11E, F), cujo conjunto pode atingir espessura entre 6 e $7 \mathrm{~m}$ e comprimento de aproximadamente $13 \mathrm{~m}$. Esta fácies é comumente interpretada como decorrência de processos de saltação e suspensão sob condições eólicas com afluxo pobre de sedimentos e espaço de acomodação insuficiente. Típica de lençóis de areia eólica.

Fácies de Arenitos com estruturas de deformação (fácies $S d$ )

Esta litofácies ocorre de maneira subordinada e abrange arenitos médios a finos, sílticos, com geometria tabular, de espessura decimétrica (10$60 \mathrm{~cm}$ ), estratificados, com estruturas de deformação. Estes arenitos dispõem-se em dois horizontes principais, bem situados e de grande persistência lateral, sendo um próximo ao contato com os arenitos fluviais da base da unidade, e outro mais espesso na porção mediana. As estruturas deformacionais compreendem laminações contorcidas, laminações convolutas e estratificações e laminações rompidas. As laminações contorcidas (Figura 11G) situam-se nas camadas de arenitos médios e finos, com cerca de 15 a $50 \mathrm{~cm}$ de espessura, de grande persistência lateral, e possuem concavidade para cima, sugerindo escape ascendente de fluídos. As estruturas de laminações contorcidas assemelham-se às descritas por Mills (1983), Obermeier et al. (1990), Cojan \& Thiry (1992), Riccomini et al. (1992), Mohindra \& Thakur (1998), Moretti (2000) e Upadhyay (2003), entre 
outros. As dobras convolutas igualmente ocorrem nas camadas de arenitos médios e finos, com cerca de 10 a $15 \mathrm{~cm}$ de espessura (Figura
11H), de grande persistência lateral, e possuem concavidade para cima ou lateral, sugestiva de escape ascendente de fluídos.
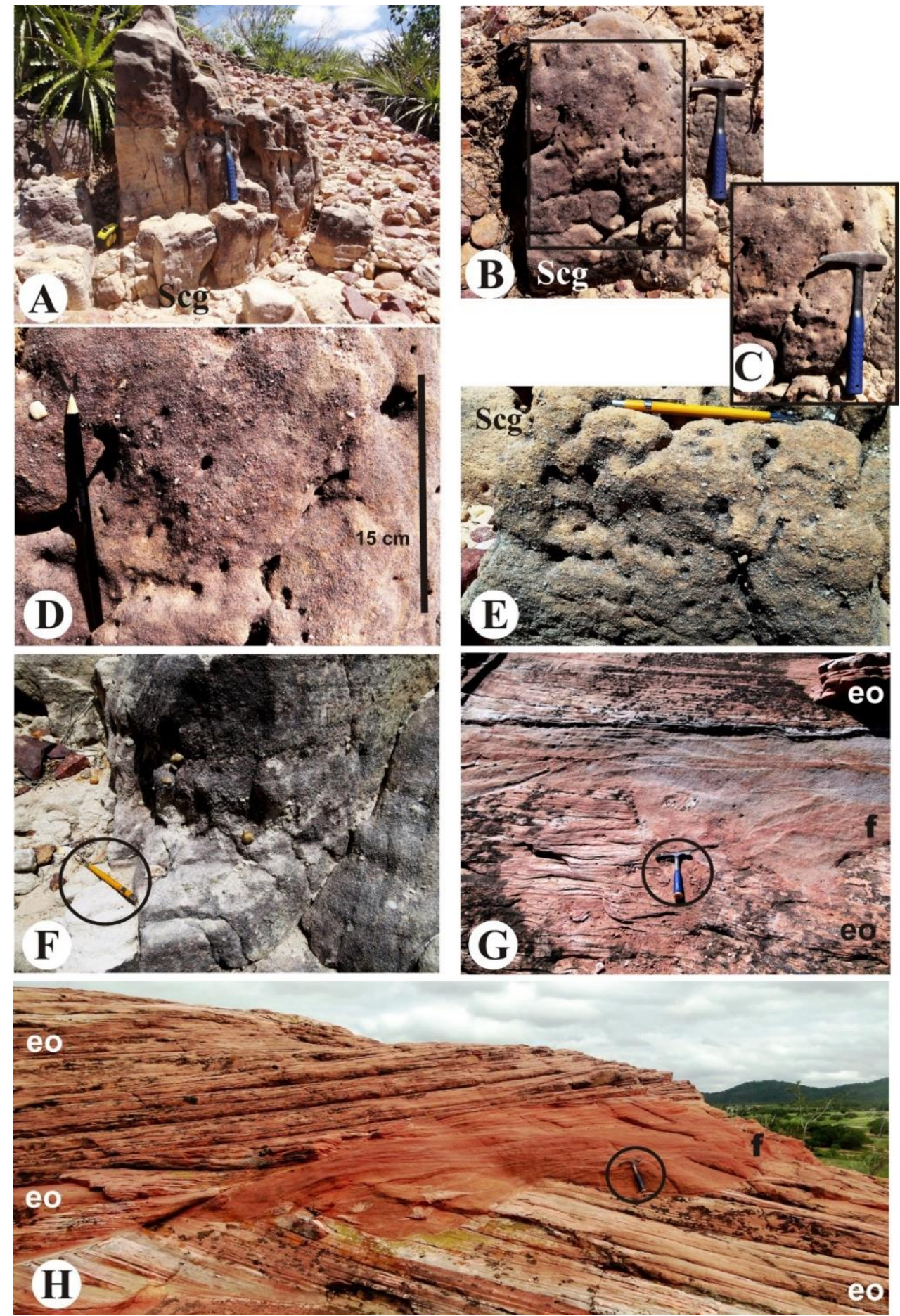

Figura 9 - Litofácies fluviais identificadas e descritas na Formação São Sebastião na região de Campos-Ibimirim. G e H) refere-se a interações flúvio-eólicas em associações de dunas eólicas. A) litofácies Scg de arenitos grossos a médios, conglomeráticos de grânulos e pequenos seixos, mal selecionados, coloração róseo-avermelhada, com estratificações cruzadas acanaladas de pequeno porte, ponto 27; B) fácies Scg e Sp de arenitos e arenitos conglomeráticos com estratificações cruzadas tabulares. Ponto 27; C) detalhe de B; D) litofácies Sm de arenitos grossos maciços. Ponto 27; E) detalhe da litofácies Scg formada por arenitos grossos a médios com seixos e grânulos esparsos, mal selecionados, com estratificação plano-paralela, e fácies Sp na base. Ponto 27; F) litofácies St de arenitos médios a grossos com seixos e grânulos esparsos, mal selecionados, com destaque para estratificações cruzadas acanaladas e geometria lenticular. Ponto 27; G e H) litofácies Sp, Sh e Sm da Associação de Fácies AF1 exibindo corpos arenosos de geometria lenticular, oscilando de 0,2 a 1,2 metros de espessura, limitados na base por superfícies irregulares e erosivas de geometria côncava na parte central, comumente em alto ângulo atenuando para as bordas. Ponto 11. Símbolos: fluvial efêmero; eo-eólico. Círculos indicam escala. 


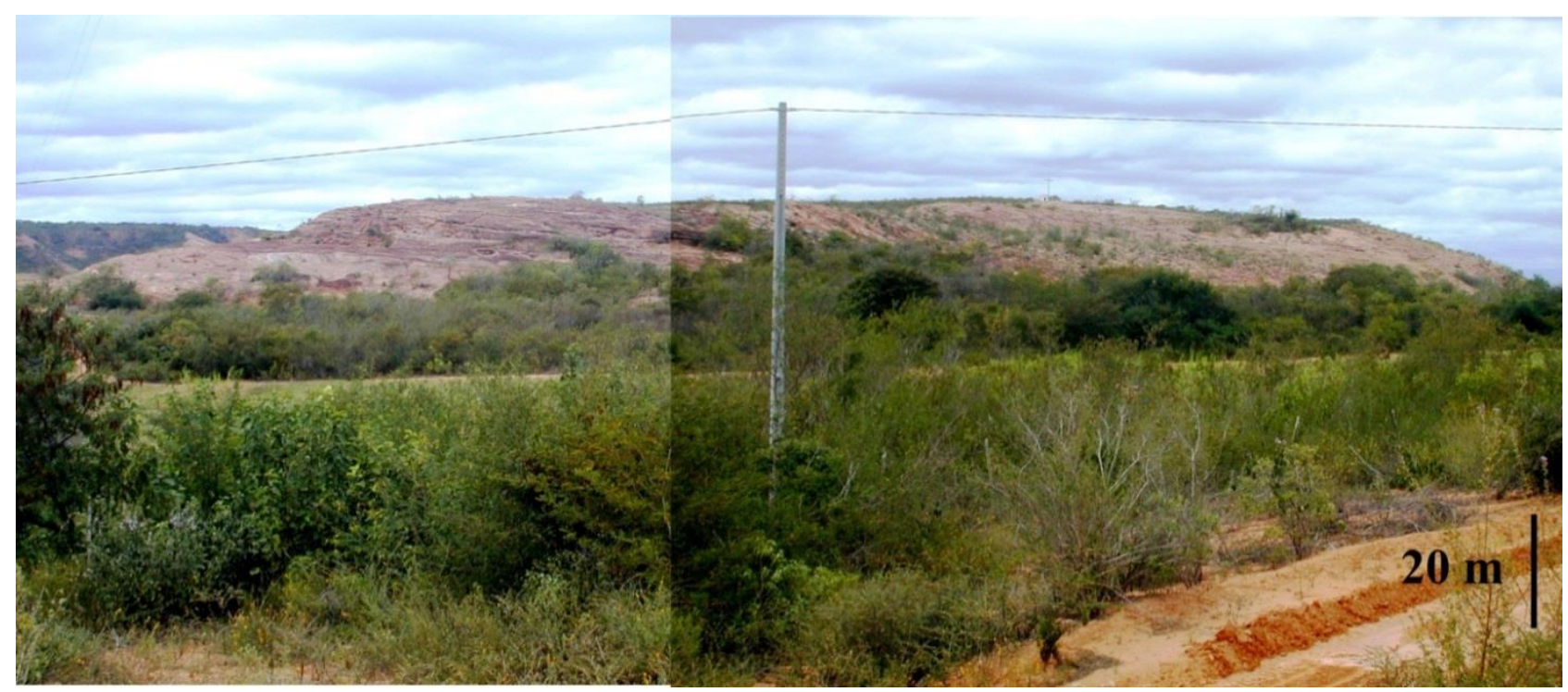

Figura 10 - Arenitos que exibem estratificações cruzadas acanaladas de grande porte interpretados como de origem eólica da Formação São Sebastião na região de Rosilho, distrito de Campos, Bacia de Jatobá. Estes arenitos compreendem a Fácies de Arenitos com Estratificação Cruzada Acanalada de grande porte (Litofácies St eólica). O morro mede cerca de $20 \mathrm{~m}$. Pontos 05 e 11.

Fácies de Arenitos Finos Laminados (fácies Slw)

Esta litofácies ocorre de maneira relativamente abrangente, sendo constituída por arenitos finos a médios, laminados, muito bem selecionados, dispostos em estratos com laminação cruzada de baixo ângulo com espessuras de $20 \mathrm{~cm}$ até $55 \mathrm{~cm}$ (Figura 11I). Os estratos cruzados são compostos por laminações de marcas onduladas eólicas.

Fácies de Arenitos com Estratificação PlanoParalela (fácies Shs)

Esta litofácies é representada por arenitos finos a médios muito bem selecionados (fácies Shs), dispostos em camadas tabulares com estratificação plano-paralela conspícua de 20 a $40 \mathrm{~cm}$ de espessura. Sua ocorrência é muito subordinada. Esta fácies foi interpretada como depósitos de interduna eólica.

Associações de Fácies da Formação São Sebastião

A partir da descrição detalhada dos afloramentos e da definição das litofácies foram identificadas três associações de fácies para os depósitos da Formação São Sebastião.

Associação de fácies de depósitos fluviais entrelaçados (AF1)

A Associação de depósitos fluviais entrelaçados (AF1) apresenta as litofácies Cm, Scg, St, Sp, St, Sm e Sh.

Os depósitos fluviais entrelaçados são dispostos em corpos arenosos em lençol que oscilam entre 0,2 e $3 \mathrm{~m}$ de espessura, limitados na base por superfícies erosivas e irregulares de geometria côncava na parte central, frequentemente em alto ângulo, que suavizam para as bordas (Figura $8 \mathrm{H}$ ). Estratos de 20 a 50 $\mathrm{cm}$ de espessura, geralmente compostos na base por extra ou intraclastos, ocorrem na base dos ciclos. Isso é mais significativo na base da unidade, no contato com a sotoposta Formação Candeias (Figuras 9A, B, C, D, E, F). Internamente os corpos fluviais são constituídos por arenitos muito grossos a médios, por vezes finos, de coloração marrom avermelhada a cinzenta, relativamente mal selecionados, com grãos subangulosos a arredondados (Figuras 10D, E, F). Os arenitos apresentam estratificação plano-paralela (fácies Sh) ou estratificações cruzadas de baixo ângulo (fácies $\mathrm{Sl}$ ), com poucas estratificações cruzadas tabulares tangenciais (Sp) (Figura 9G) e sigmoidais (Ss). Intraclastos arenosos de até $70 \mathrm{~cm}$, grânulos e seixos de quartzo são encontrados na base dos corpos arenosos (Figuras 8, 9C, D). A maioria dos intraclastos arenosos preserva a estratificação eólica primária e comumente apresentam deformações dúcteis (Figuras 9E, $12 \mathrm{~B}, \mathrm{C}$ ), estando por vezes parcialmente conectados ao pacote arenoso subjacente, sendo apenas extraídos em parte (Figuras 9H, 12 B, C). Interpretação

Os depósitos de AF1 foram desenvolvidos em planícies de rios entrelaçados, frequentes em regiões áridas a semiáridas, nas quais a presença de fluxos de rios efêmeros constituía uma rede de canais rasos. 

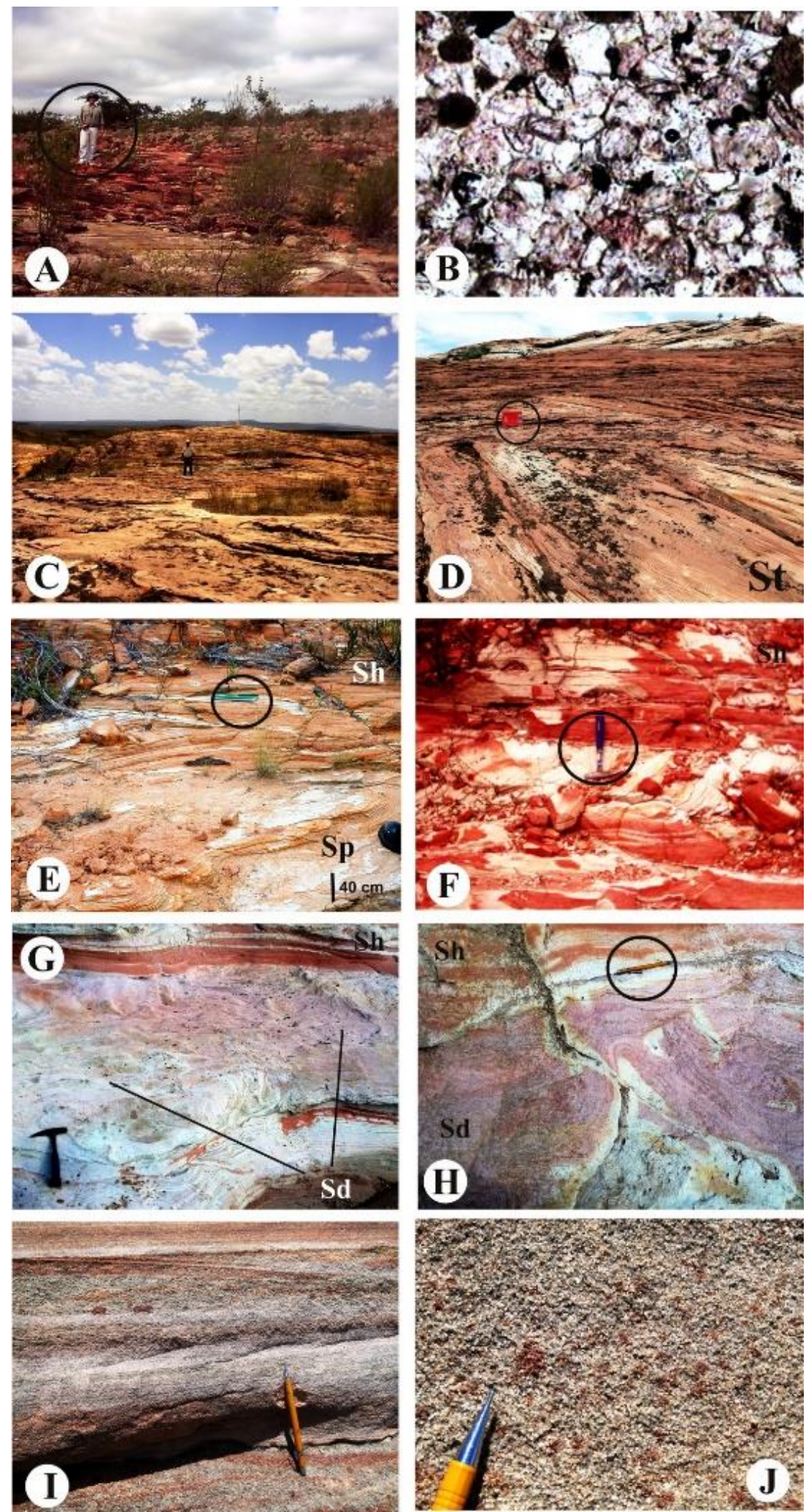

Figura 11 - Fácies eólicas identificadas e descritas na Formação São Sebastião. A) fáceis de dunas eólicas. Ponto 02; B) fotomicrografia de arenitos de dunas eólicas exibindo grãos arredondados a subarredondados de quartzo, relativa boa seleção e empacotamento fechado. Ponto 02; C) fácies de dunas eólicas composta por arenitos grossos a médios com estratificações cruzadas acanaladas (St) e de arenitos médios com estratificações cruzadas tabulares (Sp), ponto 05; D) fácies St eólica de arenitos com estratificações cruzadas acanaladas, ponto 12; E) fácies de dunas eólicas de arenitos com estratificações cruzadas acanaladas ( $\mathrm{Sp}$ ) e de arenitos com estratificação plano-paralela Sh, ponto 05; F) fácies Sh de arenitos com estratificação plano-paralela, ponto 04; G) fácies Sd de arenitos finos com estruturas deformacionais, tais como laminações contorcidas, em meio á fácies Sh, ponto 28; H) fácies $\mathrm{Sd}$ de arenitos finos com estruturas deformacionais, tais como dobras convolutas, ponto 28; (I) fácies Sl(e) de arenitos com laminação cruzadas de baixo ângulo, ponto $13 ; \mathbf{J}$ ) detalhe da fácies $\mathrm{Sl}(\mathrm{e})$ onde se sobressaem arenitos bem selecionados e arredondados. Ponto 13. Círculos indicam escala. 


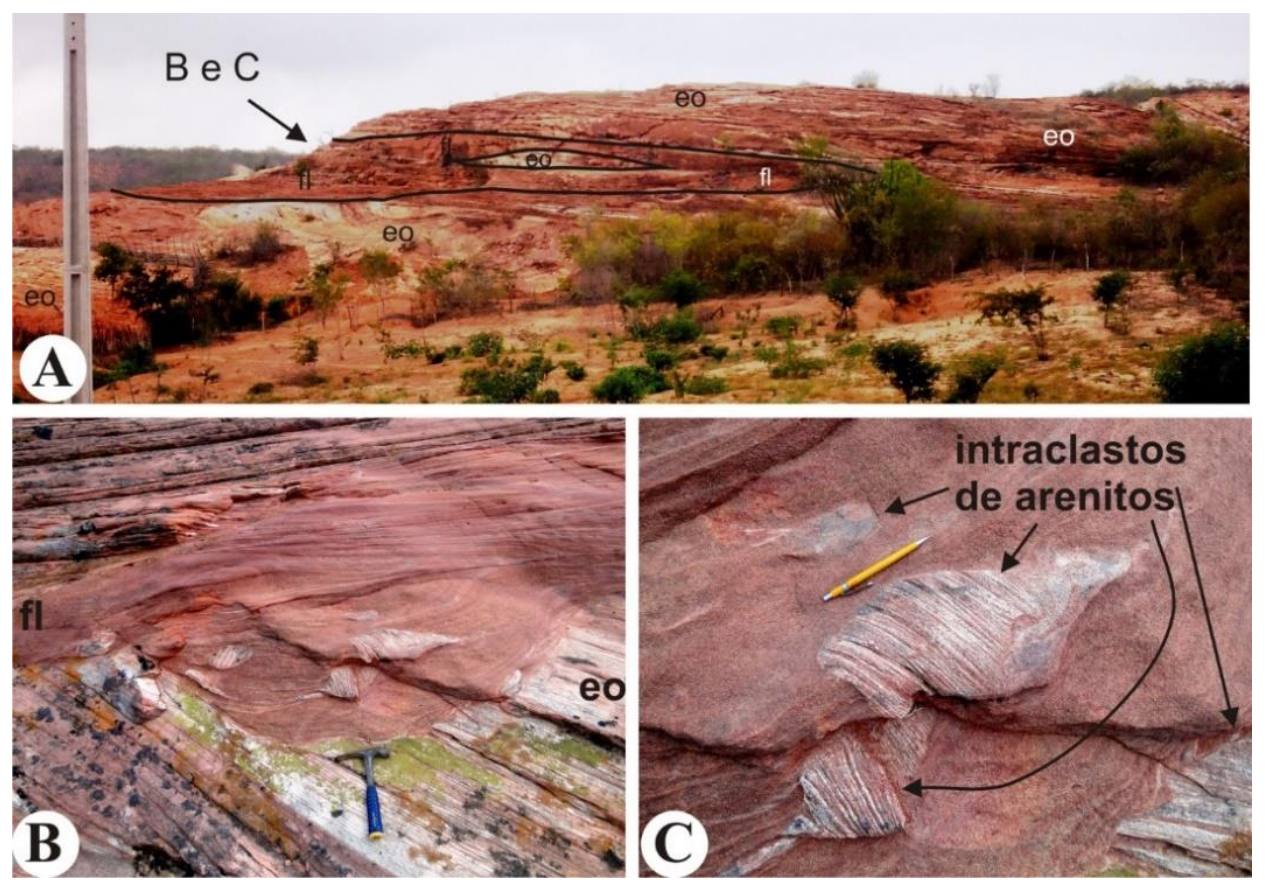

Figura 12 - Interação entre as associações de fáceis de campo de dunas eólicas (eo) e de fluviais entrelaçados (fl) da Formação São Sebastião na região de Rosilho, distrito de Campos, Bacia de Jatobá. A) Aspecto geral da interação entre as associações AF2 de dunas eólicas (eo) e AF1de fluviais entrelaçados (fl) Observar superfícies irregulares e erosivas dos arenitos fluviais. O morro mede cerca de $20 \mathrm{~m}$. Ponto 11; B) Detalhe da interação flúvio-eólica com a presença de intraclastos de arenitos das dunas eólicas na AF1 mostrando a superfície irregular e erosiva; C) Detalhe dos intraclastos de arenitos eólicos de B.

A presença de conglomerados e arenitos conglomeráticos sugere a ação de fluxos hidrodinâmicos unidirecionais trativos de alta energia associado à erosão intraformacional formada por correntes de alta energia (Miall, 1996, 2014). As seguintes características, tais como a presença de grãos na fração granulométrica correspondente ao seixo, geometria lenticular das camadas, com contatos basais erosivos na base e a capacidade de desagregação das litologias do entorno confirmam a maior competência do mecanismo transportador, sobretudo em comparação as dunas eólicas adjacentes. Além das características apontadas, a presença abundante de estruturas canalizadas de pequeno porte, o tamanho grosso dos grãos, o arcabouço suportado pelos clastos, a presença de grânulos disseminados, a pobre seleção e a raridade de estratificação plano-paralela bem desenvolvida e ausência de interfaces pelíticas nestes depósitos são fortes indicativos de deposição por canais fluviais (Scherer \& Lavina, 2005) caracterizados por correntes de alta energia de carga de fundo totalmente turbulenta, com descargas rápidas. A ocorrência de arenitos maciços (Sm), interpretados como fluxo hiperconcentrado, em associação ao explanado acima, levam à explicação de deposição por canais fluviais efêmeros e de alta energia. (Miall, 1996; Miall \& Jones, 2003; Miall, 2014). O caráter efêmero é destacado pelos indicadores de aridez das rochas (Miall, 1996; Miall, 2014) tais como a forte presença das litofácies Sl e Sh, indicativas de fluxo raso com alta energia, e presença de corpos de sedimentos eólicos laminados e de geometria em cunha próximos as superfícies limítrofes destes arenitos.

Dessa forma, AF1 é interpretada como depósitos de rios efêmeros ou wadis, que são caracterizados pela baixa razão água/sedimento e por um regime tipicamente torrencial associado a chuvas esporádicas.

Associação de fácies de campo de dunas eólicas (AF2)

A associação de fácies de campo de dunas eólicas (AF2) é a principal associação de fácies da área investigada, estando presente em toda a seção investigada da Formação São Sebastião. Associa-se com os arenitos com laminação plano-paralela e estrutura de adesão (adhesion ripples) da associação de fácies de lençóis de areia eólicos (AF4) e com Associação de depósitos fluviais entrelaçados canalizados (AF1). A AF2 ocorre na forma de estratos com estratificação cruzada acanalada de pequeno 
porte até grande porte a gigante (espessura entre 0,2 até mais de $20 \mathrm{~m}$ ), geometria tabular de grande extensão lateral, por vezes separados por superfícies sub-horizontais (Figuras 11B, C, 12A), ou com contatos superior e inferior definidos por superfície erosiva de baixo ângulo, entre 2 e $6^{\circ}$ de inclinação, com espessura da ordem de uma a duas dezenas de metros e continuidade lateral podendo atingir dezenas de metros. A AF2 envolve as fácies de Arenitos com Estratificação Cruzada Acanalada de grande porte (St eólica), arenitos com estratificação cruzada tabular e tangencial (Sp eólica), arenitos com laminações onduladas e estrutura de adesão (Sl).

A Fácies de Arenitos com Estratificação Cruzada Acanalada de grande porte (Litofácies St eólica) constitui a mais conspícua fácies da associação AF2 e surge como sucessão de séries com contatos erosivos na base, que se entrecortam. Os contatos erosivos que balizam as séries estabelecem superfícies de superimposição (sensu Mountney, 2006), que refletem a erosão causada pelo processo de migração dessas superfícies (Figura 11D). Internamente às séries, sobrevêm igualmente superfícies erosivas as quais delimitam estratificações cruzadas adjacentes com ângulos de inclinação suavemente diferentes. Tais contatos erosivos internos às séries foram aqui considerados superfícies de reativação truncadas pelas superfícies de superimposição (Figura 11D).

O contato erosivo na base da fácies Scg trunca as superfícies de superimposição da fácies $\mathrm{St}$ eólica, de maneira que as duas fácies ocorrem intercaladas. A superfície erosiva originada pela fácies Scg possui continuidade lateral, apresenta baixo ângulo de mergulho e sentido de mergulho oposto ao sentido de migração das dunas da fácies St eólica, definindo, assim, uma superfície de migração de interdunas (Figuras 13C, D) sensu Kocurek (1996). Segundo Mountney (2006), uma superfície de migração de interduna assinalada por um nível de grânulos e seixos, como é o caso da fácies Scg, pode representar um pavimento de deflação em interduna seca (Figuras 13E, F).

Os estratos cruzados são constituídos, nas porções mais íngremes dos foresets, por lâminas com gradação inversa interna, geradas por processos de fluxo de grãos. Na base dos sets, os estratos tangenciam a superfície basal, sendo constituídos por laminações de marcas onduladas eólicas (litofácies $\mathrm{St}(\mathrm{e})$ ), como observado na figuras 13C, D. As superfícies inclinadas das estratificações cruzadas passam lateralmente para a zona interdunas por dezenas de metros, ocasionando a ocorrência de extensas séries de estratificações cruzadas de baixo ângulo de mergulho e espessura métrica.

Os arenitos com estratificação cruzada tabular e tangencial (Fácies Sp) apresentam estratificações cruzadas dos tipos tabular e tangencial de pequeno a médio porte (sets de 0,2 a $1,5 \mathrm{~m}$ de espessura) (Figura 14) e o conjunto dos estratos (coset) tem cerca de $3 \mathrm{~m}$ de espessura (Figuras 13C, D).

As estratificações cruzadas possuem mergulhos entre $15^{\circ}$ e $36^{\circ}$, com contatos angulares com a horizontal (cuneiforme) e direção de $200^{\circ}$ a $350^{\circ} \mathrm{Az}$. Os estratos frontais (foresets) são constituídos por fluxo de grãos (grain flow) e queda de grãos (grain fall), bem como de laminação cruzada cavalgante subcrítica transladante (Figura 11I), com mergulho suave, ou finamente laminada (pinstripe lamination) (Figura 11E). Particularmente, as lâminas exibem variações no tamanho dos grãos, boa seleção e gradação inversa. Nessa associação é extremamente abundante a presença de grãos bem arredondados recobertos por uma película de óxido-hidróxido de ferro. Os estratos de fluxo de grãos possuem, em média, $2,5 \mathrm{~cm}$ de espessura, podendo atingir $4 \mathrm{~cm}$ de espessura (Figura 11J). As lâminas com fluxo de grãos caracterizam-se pelo alto ângulo de mergulho $\left(23^{\circ}\right.$ a $\left.27^{\circ}\right)$ e pela gradação inversa. As paleocorrentes medidas nos estratos cruzados indicam a migração das dunas eólicas dominantemente para os quadrantes NW e SW e, subordinadamente, para NE.

\section{Interpretação}

A boa seleção, o arredondamento e a esfericidade dos grãos, juntamente com as estratificações cruzadas de grande porte compostas por depósitos de fluxo de grãos e marcas onduladas eólicas, permitem interpretar essa associação de fácies como depósitos residuais de dunas eólicas (Hunter, 1977a, b; Kocurek \& Dott, 1981). A geometria acanalada das estratificações cruzadas sugere que estas dunas foram principalmente de cristas do tipo barcana ou barcanóide (sensu McKee, 1966, 1979a, b). 

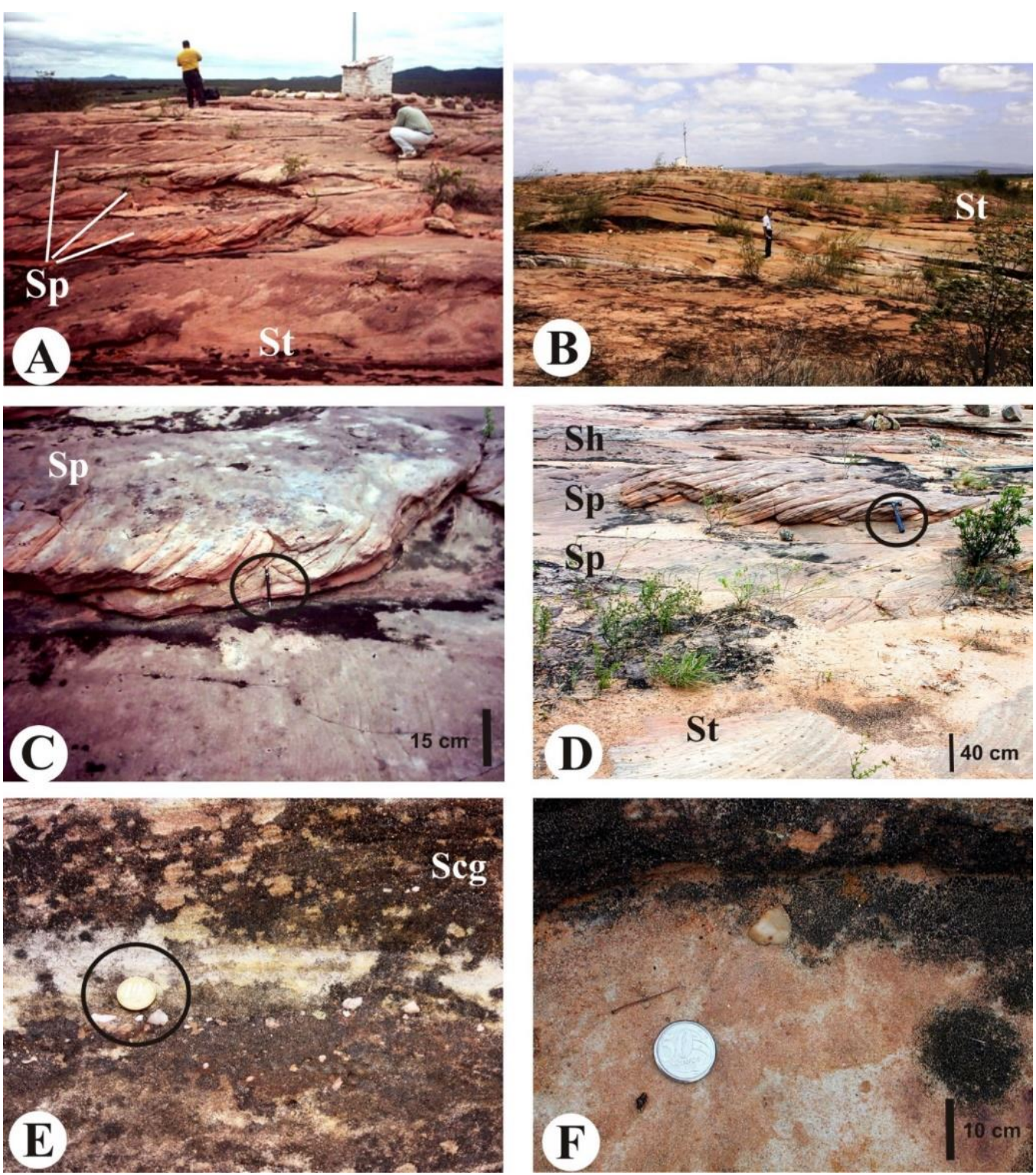

Figura 13 - Fácies de dunas eólicas identificadas e descritas na Formação São Sebastião. A) fáceis Sp de arenitos com estratificações cruzadas tabulares sucessivas; B) fáceis St de arenitos com estratificações cruzadas acanaladas de grande porte; C) detalhe da fácies Sp; D) arenitos com estratificações cruzadas tabulares sucessivas da Fácies Sp; (E e F) fáceis Scg de arenitos conglomeráticos de pequenos seixos trunca as superfícies de superimposição da fácies St eólica, de maneira que as duas fácies ocorrem intercaladas. A superfície erosiva originada pela fáceis Scg possui continuidade lateral, apresenta baixo ângulo de mergulho e sentido de mergulho oposto ao sentido de migração das dunas da fáceis $\mathrm{St}$ eólica, definindo, assim, uma superfície de migração de interdunas. Círculos indicam escala. Ponto 05.

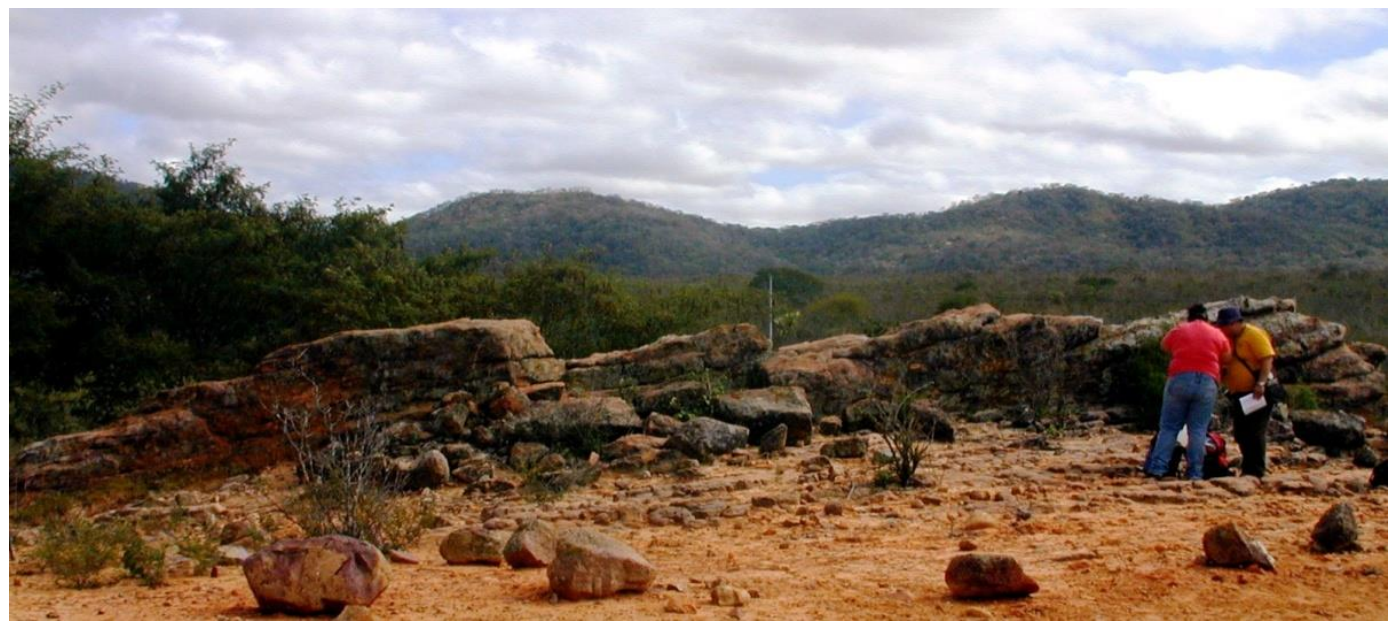

Figura 14 - Arenitos médios a grossos estratificados da litofácies St. Estratificação cruzada acanalada de grande porte. Notar mergulho das camadas para NW (embasamento metamórfico ao fundo). Ponto 01. 
As superfícies sub-horizontais que limitam os sets de estratificações cruzadas podem ser interpretadas como de primeira ordem, geradas pelo cavalgamento de dunas eólicas (Mountney, 2006).

Os arenitos desta associação com estratificação cruzada de médio porte, formada por fluxo e queda de grãos, são interpretados como depósitos de dunas eólicas originadas pela migração de macroformas onduladas (Hunter, 1977b; Kocurek \& Dott, 1981). A migração dessas formas de leito origina superfícies de primeira ordem (Mountney, 2006).

A espessura dos depósitos de fluxo de grãos sugere que as dunas tinham entre 0,5 e $3 \mathrm{~m}$ de altura (Kocurek \& Dott, 1981). A laminação cruzada cavalgante subcrítica é formada pela migração de marcas onduladas de pequena amplitude e grande comprimento de onda (ripples). $\mathrm{O}$ mecanismo trativo de arraste associado à suspensão dessas microndulações causa o cavalgamento das ondulas, cuja superposição forma lâminas sub-horizontais ou pseudoacamamentos (McKee \& Weir 1953; McKee, 1966; Hunter 1977b).

As superfícies de reativação da Formação São Sebastião foram formadas pela erosão na face de deslizamento da duna (lee-slope) seguida por uma nova sedimentação associada a mudanças na assimetria das dunas e na direção e velocidade de migração dos ventos (Kocurek, 1996). Nesta associação as superfícies de reativação e de migração de interduna são exemplos de superfícies limitantes presentes (Brookfield, 1977).

As superfícies de reativação exibem mergulhos suaves $\left(15^{\circ}\right.$ a $\left.20^{\circ}\right)$ e cortam os foresets das estratificações cruzadas, enquanto as superfícies de migração de interdunas se caracterizam por limites erosivos levemente inclinados, com mais de $50 \mathrm{~m}$ de extensão. De outro modo, as superfícies que limitam sets ou cosets de estratos cruzados, sub-horizontais ou com mergulho inverso ao das estratificações cruzadas, denominam-se de superfície de interduna (sensu Kocurek, 1996). Estas superfícies desenvolvem-se pelo cavalgamento subcrítico de dunas eólicas ou draas. As superfícies internas aos cosets, que mergulham em mais baixo ângulo e balizam sets com sentido de mergulho com divergência superior a $300 \mathrm{em}$ relação aos estratos cruzados sobrejacentes, são denominadas de superfícies de sobreposição (Kocurek, 1996). As superfícies de sobreposição são formadas pela migração de dunas menores na direção obliqua em relação à face frontal de draas (Kocurek, 1996). A geometria acanalada das estratificações cruzadas de grande porte indica que estas dunas foram principalmente de cristas do tipo barcana ou barcanóide (sensu McKee, 1966, 1979a, b).

Pequenos conjuntos de arenitos de estratificação cruzada de baixo ângulo são ajuizados por representar a preservação parcial das camadas inferiores, assintóticas das mesmas dunas. Os arenitos com ondulações de correntes e estratificação cruzada tabular relacionados com a fácies de Duna eólica podem ter sido originados por processos tanto eólicos como aluviais, envolvendo a interação das correntes de inundação de águas rasas (formação de estratificação tabular e ondulações de corrente), correntes de vento no lago raso de interduna de areia eólica retrabalhados por sedimentos expostos ao ambiente subaéreo.

Associação de fácies de interdunas eólicas (AF3)

A associação de fácies de interdunas eólicas (AFIE) inclui arenitos finos a médios, moderadamente selecionados, possuindo grãos arredondados e com alta esfericidade. Estes arenitos são organizados em pacotes tabulares com 0,3 a 1,5 m de espessura, intercalados aos sets de estratificação cruzada (Figura 15). Tais pacotes são caracterizados por laminações planoparalelas e cruzadas de baixo ângulo compostas essencialmente por laminações de marcas onduladas eólicas (litofácies Sh(e) e Sl(e)). Localmente, observam-se dobras convolutas e estruturas de adesão (Adhesion ripples).

\section{Interpretação}

Os arenitos com estratificações planoparalelas e cruzadas de baixo ângulo, compostas por laminações de marcas onduladas eólicas e intercalados aos sets de dunas eólicas são interpretados como depósitos de interdunas eólicas (Ahlbrandt \& Fryberger, 1981; Mountney, 2006, Dias \& Scherer, 2008; Jones et al., 2016). As dobras convolutas e laminações contorcidas observadas formaram-se por processos de fluidização, originados pelo peso da duna eólica sobrejacente (Mountney \& Thompson 2002, Dias \& Scherer 2008), como observado nas figuras $11 \mathrm{G}, \mathrm{H}$. 


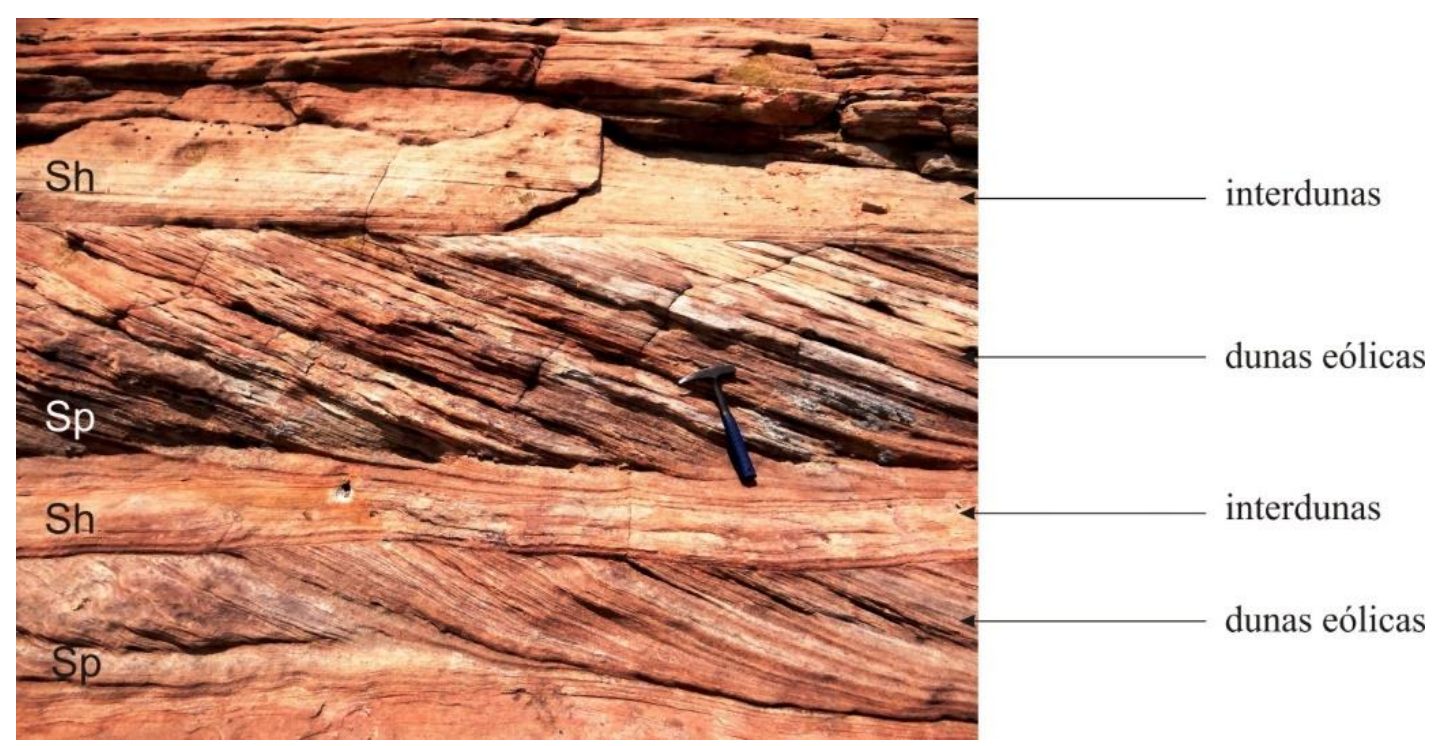

Figura 15 - A associação de fácies de interdunas eólicas (AF3) é caracterizada por laminações plano-paralelas e cruzadas de baixo ângulo compostas essencialmente por laminações de marcas onduladas eólicas (litofácies $\operatorname{Sh}($ e) e $\mathrm{Sl}(\mathrm{e})$ ) que se interpõem entre dunas eólicas.

O conjunto apresenta características sedimentares que sugerem tratar-se de depósitos interdunas, com deposição eólica e subaquosa, com flutuações do lençol freático. A presença de estruturas de adesão é uma clara indicação de uma fonte de areia seca e de uma superfície deposicional úmida ou molhada (Kocurek \& Filder, 1982). Quando em contato com a superfície úmida, a areia seca soprada pelo vento forma estruturas de adesão. Essa umidade é comum em áreas fortemente controladas pelo lençol freático e/ou onde ocorrem chuvas eventuais. Segundo Mountney (2006), interdunas úmidas são formadas quando o lençol freático sobe até ou acima da superfície deposicional devido a períodos em que a interduna é contínua ou episodicamente exposta a inundações.

Associação de fácies de lençóis de areia eólicos (AF4)

A associação de fácies de lençóis de areia eólicos (AF4) ocorre de forma subordinada. É formada por um pacote de aproximadamente $3 \mathrm{~m}$ de espessura, composto por arenitos médios a grossos, quartzosos, bem selecionados e com laminações cruzadas de baixo ângulo ( $\mathrm{Sl}(\mathrm{e})$ ), compostos por laminações transladantes cavalgantes, inversamente gradadas, com espessuras de 2 a $8 \mathrm{~mm}$ (Figura 16). A associação AF4 foi subdividida em dois conjuntos de fácies: CI) camadas planas com base deformada; CII) camadas planas constituídas por diversos tipos de laminações/estratificações internas. $\mathrm{O}$ conjunto CI é composto de arenitos finos a muito finos, moderadamente selecionados com estratificação plano-paralela e de baixo ângulo (S1), acamamento maciço (Sm), estruturas de deformação (Sd). Essa sucessão tem mais de 20 $m$ de espessura e posiciona-se principalmente na porção inferior da seção estudada. É formada por camadas com grande extensão lateral de até 300 $\mathrm{m}$ (Figuras 16A, B, C, D). O conjunto CII consiste em arenitos finos a médios, bem selecionados e com grãos bem arredondados, exibindo estratificação plano-paralela (Sh) (Figura 16E), laminação plano-paralela e laminação cruzada cavalgante transladante (Sl). As laminações cruzadas cavalgantes formam lâminas sub-horizontais e/ou com baixo ângulo (menos de $5^{\circ}$ ), com 1 a $4 \mathrm{~cm}$ de espessura e gradação inversa (Figura 16A). Também ocorrem arenitos finos a grossos, com grânulos e seixos esporádicos, preenchendo geometria de canal e com estratificação cruzada acanalada de pequeno a médio porte.

No conjunto comumente ocorrem intercalações de laminação e adhesion warts. As laminações de adesão formam laminações irregulares e crenuladas que persistem por dezenas de metros, frequentemente associadas a estruturas de deformação. As verrugas de adesão (adhesion warts) formam pequenas projeções ou montículos centimétricos na forma de arco ou semiarco (Figura 16F). Essas estruturas marcam o topo de camadas centimétricas que formam ciclos de ressecamento ascendente (dryingupward) (Kocurek \& Dott, 1981) e estão presentes na base e na porção média da Formação São Sebastião. 

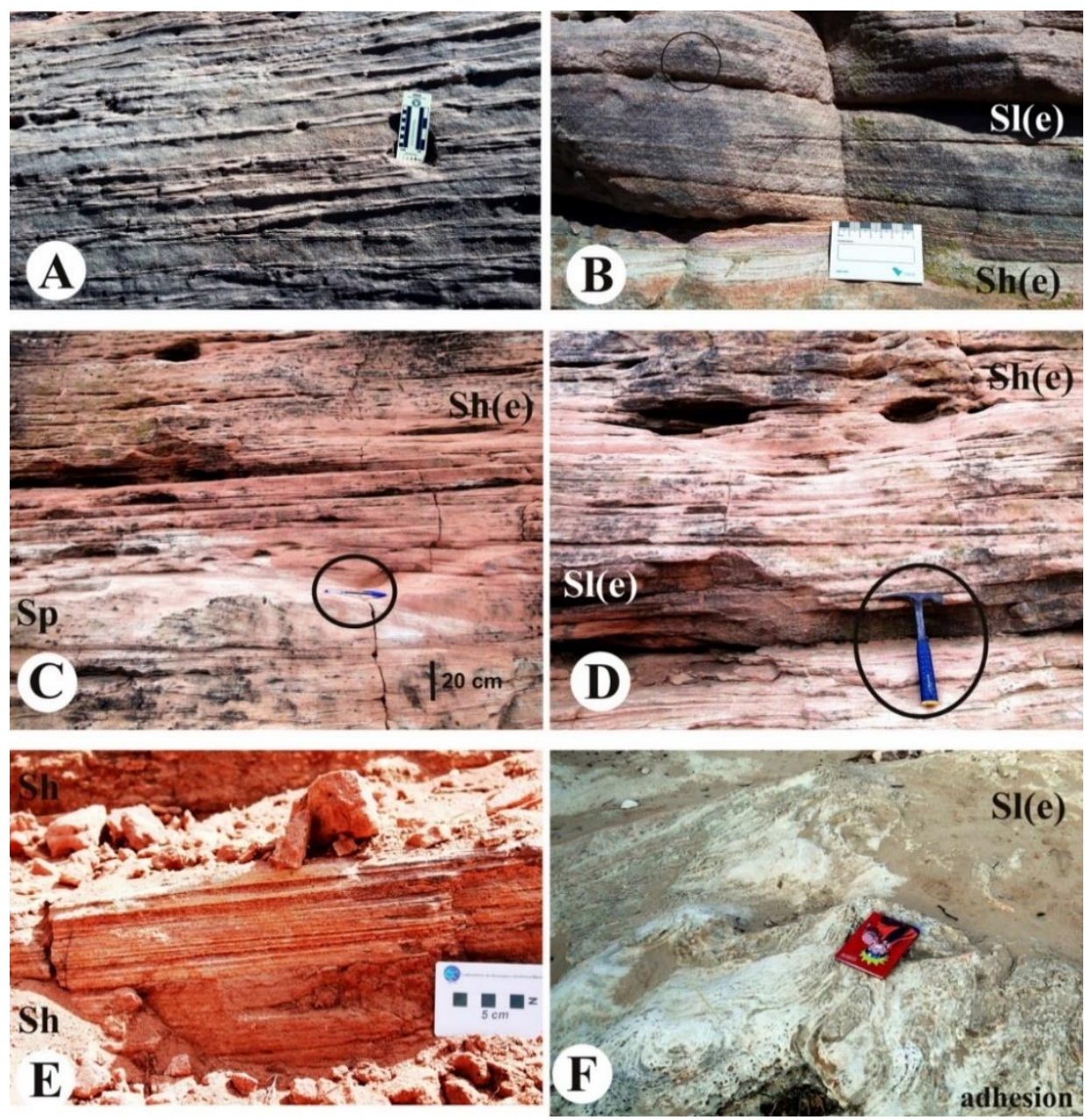

Figura 16 - Fácies de lençóis de areia eólicos (AF4) identificadas e descritas na Formação São Sebastião. A) fácies Sh(e) de arenitos com estratificação plano-paralela e bimodalidade conspícua; B) fácies de arenitos com laminação planoparalela (Sh(e)) e de arenitos com laminações cruzadas de baixo ângulo (Sl(e)); C e D) fácies de arenitos com laminação plano-paralela $(\mathrm{Sh}(\mathrm{e}))$ e de arenitos com laminações cruzadas de baixo ângulo (Sl(e)); E) fácies Sht arenitos com estratificação plano-paralela; F) fácies $\mathrm{Sl}(\mathrm{e})$ de arenitos finos com estruturas de adesão (adhesion). Círculos indicam escala.

\section{Interpretação}

Os arenitos com laminações cruzadas de baixo ângulo e gradações inversas internas aos estratos podem ser interpretados como lençóis de areia eólicos formados pela migração e cavalgamento de marcas onduladas eólicas subcríticas sobre uma superfície deposicional seca (Hunter, 1977a, b).

O conjunto de fácies representa a migração de dunas eólicas zibar de pequena amplitude, com topo aplainado pelo retrabalhamento eólico. A migração de formas onduladas de origem eólica (wind ripples) é indicada pela presença de laminações sub-horizontais com gradação inversa (Hunter, 1977a, b). O fluxo em lençol, que se espraiava sob condições de regime de fluxo inferior a superior, deu origem a arenitos com estratificação plano-paralela nas planícies dos lençóis arenosos. Localmente, a máxima velocidade da corrente causou fluxos confinados em canais rasos e estreitos (gutter casts) com migração de dunas subaquosas (3D). Feições crenuladas são interpretadas como estrutura de adesão. Essa estrutura é formada pela adesão de grãos de areia seca soprados pelo vento sobre superfícies úmidas (Kocurek \& Fielder, 1982). As laminações de adesão indicam sequências de ressecamento ascendente (dry-upward) e, diferentemente das demais estruturas de adesão, podem ser formadas em grandes áreas, dependendo, principalmente, do teor de umidade (até $80 \%$ ).

A alternância de laminações eólicas com estruturas de adesão reflete mudanças no teor de umidade desses depósitos (Chakraborty \& Chaudhuri, 1993). Planícies arenosas formadas pelo vento ou por fluxo em lençóis consistem principalmente em estratificação cruzada de baixo ângulo formada por ondulações ou queda de grãos. Normalmente ocorrem em áreas 
marginais aos campos de dunas (Fryberger et al., 1979). O modelo proposto aqui sugere que essas planícies arenosas foram submetidas esporadicamente a alternâncias de retrabalhamento eólico e inundações episódicas (flash floods). Durante a fase seca, formas de leito de pequeno a médio porte, geralmente com o topo arrasado pela intensa deflação, foram desenvolvidas com a formação de marcas onduladas (Figuras 13E, F). Inundações episódicas sob regime de fluxo superior e inferior geraram $\mathrm{o}$ espraiamento das areias e retrabalhariam a planície de deflação preestabelecida. Além disso, formaram redes de canais rasos com dunas subaquosas de baixa amplitude. Uma nova fase de deflação subsequente retrabalharia todo o depósito subaquoso.

De acordo com Kocurek \& Nielson (1986), depósitos de lençóis de areia eólicos manifestamse em sistemas desérticos, sob condições climáticas desfavoráveis ao desenvolvimento de dunas com faces frontais bem formadas. Os autores apontam, ainda, as causas para a formação de lençóis de areia eólicos, tais como, condições de lençol freático alto, inundações recorrentes, granulometria grossa dos sedimentos, presença de vegetação, superfície de cimentação. Este parece ser o caso dos sedimentos desta porção da Formação São Sebastião na área investigada.

\section{Sistemas Deposicionais da Formação São Sebastião}

A partir da combinação vertical e lateral das associações de fácies, foi possível definir dois sistemas deposicionais relacionados: sistema fluvial e sistema eólico.

\section{Sistema Fluvial}

$\mathrm{Na}$ região de Campos-Ibimirim as fácies fluviais da Formação São Sebastião são subordinadas às fácies eólicas, discutidas a seguir. O sistema fluvial da Formação São Sebastião é composto unicamente por uma associação de fácies - depósitos fluviais entrelaçados (AF1). Morfologicamente os canais fluviais podem ser classificados como rios entrelaçados e possuem uma geometria em lençol. Tais arenitos de geometria em lençol são arranjados pela justaposição lateral e vertical de macroformas de acresção frontal (elemento DA) e formas de leito arenosas (elemento SB), formando corpos arenosos multiepisódicos e multilaterais. As macroformas possuem altura variada, em média $0,5 \mathrm{~m}$, revelando a profundidade mínima do canal fluvial. As características do elemento DA, dentre as quais o caráter unidirecional de corrente, formas de leito arenosas a conglomeráticas formando preenchimento de escavações pequenas e rasas que se entrecortam, a geometria tabular, a dominância de macroformas de acresção frontal, associada à ausência de depósitos de lençol de areia (elemento LS), apontam para um modelo deposicional de canais efêmeros com fluxo desconfinado (Miall, 1985, 1988, 1996, 2014; Bridge, 2006) no contexto de sistemas fluviais entrelaçados efêmeros.

A análise de paleocorrentes fluviais foi realizada em três estações de medidas (vide Figura 2). As paleocorrentes medidas possuem padrão de dispersão para $\mathrm{S}$ e $\mathrm{SW}$ e, subordinadamente, para W. Os padrões de paleocorrentes obtidos são coerentes com sistema fluvial. Também denotam contribuição de áreas fontes localizadas a $\mathrm{N}$ e $\mathrm{E}$, ou seja, o embasamento do Maciço Pernambuco-Alagoas (Figura 17).

\section{Sistema Eólico}

Os depósitos eólicos formam pacotes de 0,5 a mais de $20 \mathrm{~m}$, sendo constituídos de arenitos finos a grossos, bem selecionados, com estratificações cruzadas tabulares e acanaladas, além de estratificações plano-paralelas. Os estratos plano-paralelos são, por sua vez, distinguidos por laminações transladantes cavalgantes de marcas onduladas eólicas, sendo interpretados como lençóis de areia eólicos. Os sets de estratos cruzados são formados pela alternância de lâminas de fluxo de grãos e queda livre de grãos na porção mais íngreme dos foresets, intercalando-se em direção a base com laminações de marcas onduladas eólicas, sendo interpretados como depósitos residuais de dunas eólicas. Os estratos de dunas eólicas apresentam padrão de paleocorrente média para NW, e outro para SW.

A fácies $\mathrm{St}(\mathrm{e})$ é predominante no elemento DB (dunas barcanoides sensu Godinho et al., 2013) e ocorre como sucessões de pacotes arenosos com contatos erosivos na base, que se entrecortam. Os contatos erosivos que balizam as séries marcam superfícies de superimposição (sensu Mountney, 2006), refletindo a erosão causada pelo processo de migração dessas superfícies (Figuras 10, 11C, D). 


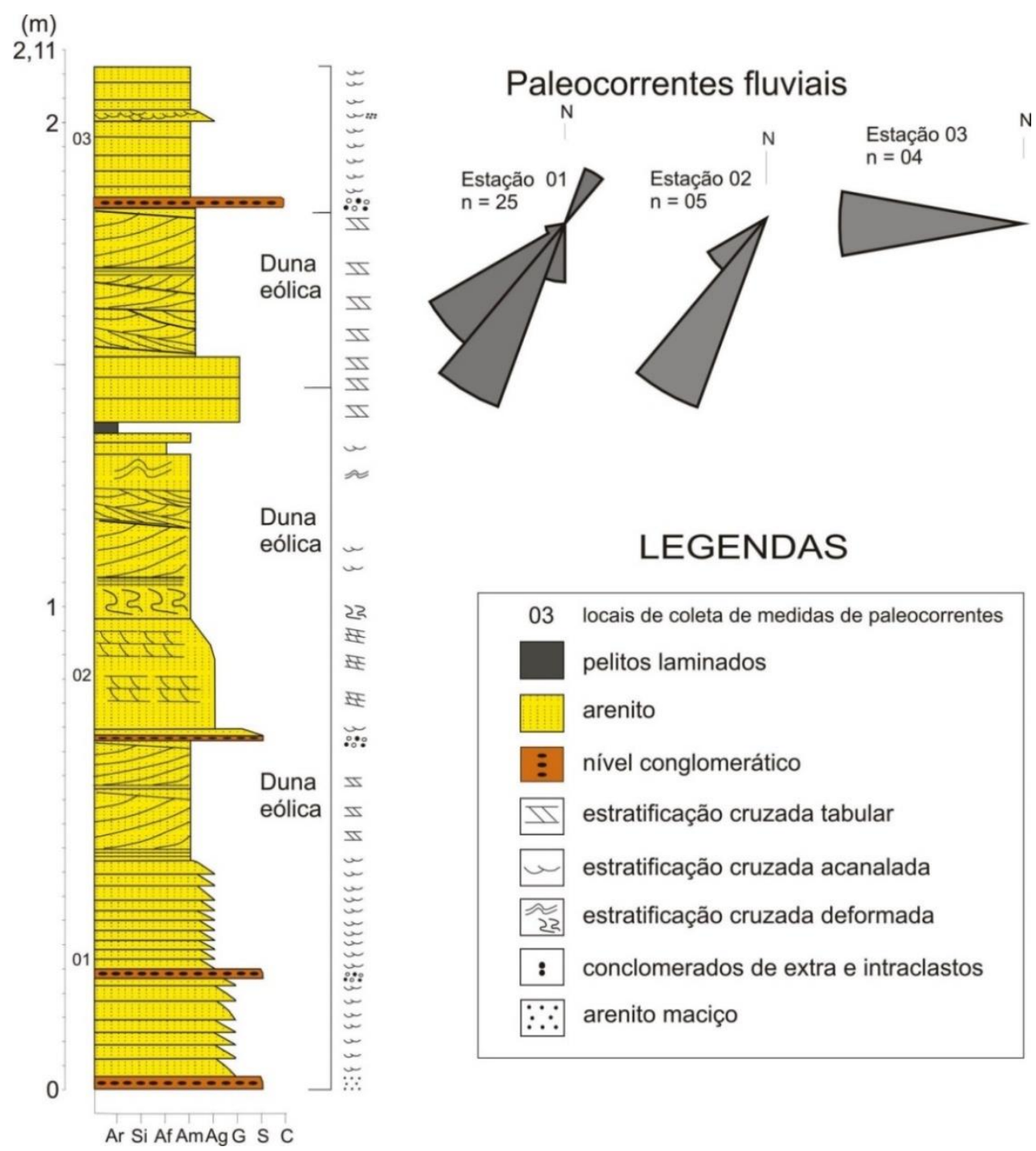

Figura 17 - Seção colunar composta dos depósitos predominantemente fluviais da Formação São Sebastião.

Dentro das séries, aparecem superfícies erosivas, que delimitam estratificações cruzadas adjacentes com ângulos de inclinação levemente caracterizados.

Tais contatos erosivos dentro dos pacotes arenosos representam superfícies de reativação, truncadas pelas superfícies de superimposição (Figura 11D).

O elemento DB (dunas barcanoides) apresenta geometria tabular, dezenas de metros de espessura e continuidade lateral de várias dezenas de metros, e está aqui sendo interpretado como produto de um campo de dunas eólicas barcanoides, em razão da associação de fácies dominada por estratificações cruzadas acanaladas de grande porte e à apresentação de superfícies erosivas de superimposição, reativação e migração de interduna, conforme disposto em vários trabalhos (Kocurek, 1996; Mountney, 2006; Godinho et al., 2013). Representa verdadeiro campo de dunas (erg), formado por diversos corpos de draas.

Segundo Mountney (2006), uma superfície de migração de interduna marcada por um nível de grânulos e seixos, como é o caso da fácies $\mathrm{Scg}$, pode representar um pavimento de deflação em interduna seca (Figuras 13E, F).

As exposições de arenitos eólicos da Formação São Sebastião são caracterizadas dominantemente por arenitos finos a grossos, com laminações de baixo ângulo de marcas onduladas eólicas, interpretados como lençóis de areia eólicos, e/ou estratos cruzados tabulares, compostos por lâminas de fluxo de grãos (topo de camada) e de marcas onduladas eólicas (base de camada), interpretados como depósitos residuais de dunas eólicas. Intercalados com os depósitos eólicos, ocorrem arenitos finos a médios, maciços, com estratificação planoparalela e, mais raramente, com estratificação cruzada acanalada, interpretados como depósitos fluviais canalizados (Figura 18). 


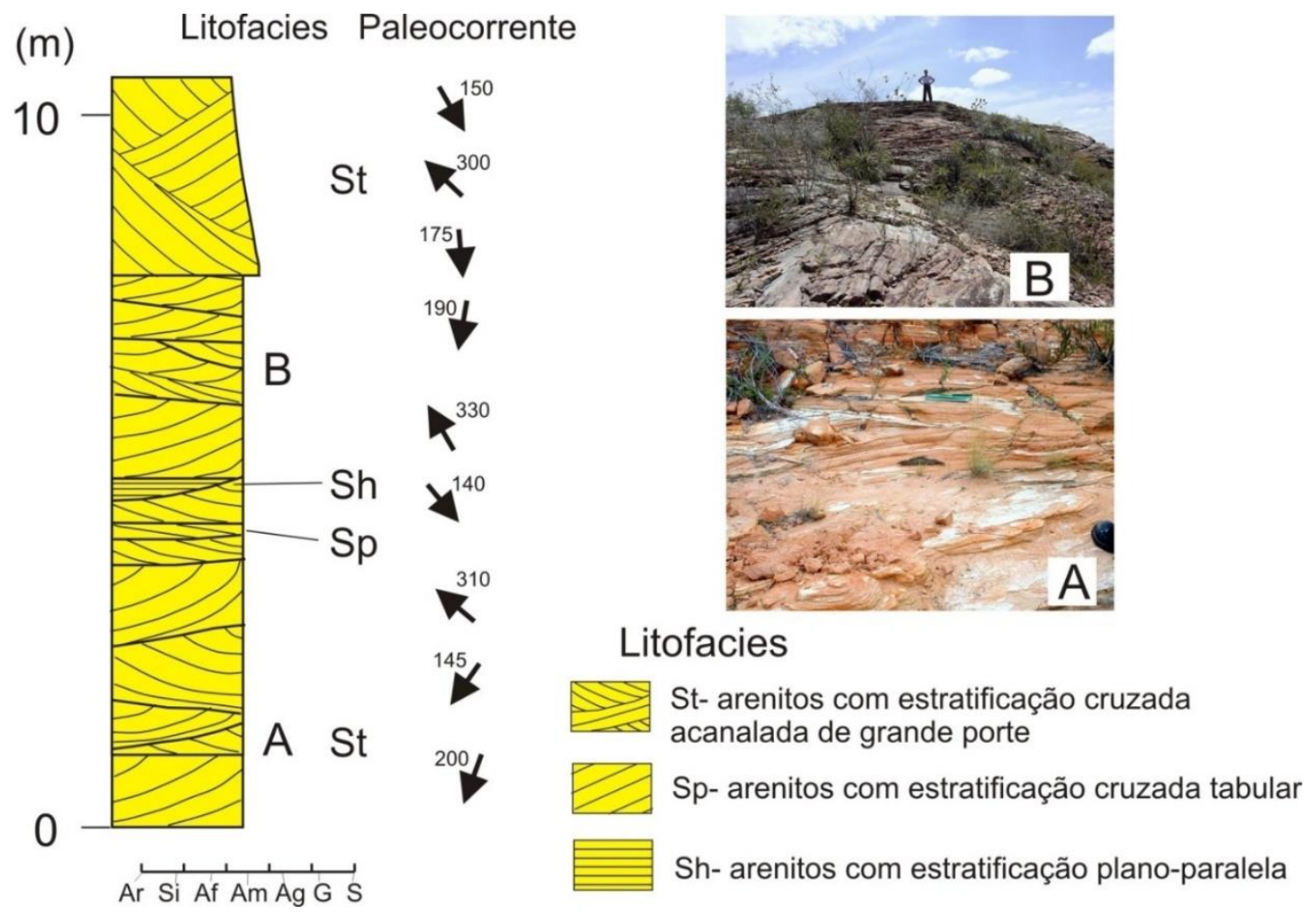

Figura 18 - Seção colunar de detalhe dos depósitos de dunas eólicas da Formação São Sebastião. A e B) detalhe dos arenitos com estratificações cruzadas acanaladas de grande porte da fácies de Dunas Eólicas. Ponto 04.

\section{DISCUSSÃO}

O modelo aqui proposto pode ser sintetizado em dois sistemas deposicionais interligados: sistema fluvial entrelaçado de grande energia, composto por canais fluviais preenchidos por barras de granulação grossa (elemento SB) e barras de granulação fina (elemento DA), e sistema eólico constituído por campo de dunas (elemento DB) e depósitos de interduna e lençol de areia (elemento ID). O sistema fluvial da base parece ter sido retrabalhado por processos eólicos que se instalaram na bacia, fato este comum nestes sedimentos (El-Baz et al., 2000, Veiga \& Spalletti, 2007; Spalletti et al., 2010).

Os estratos de arenitos da Formação São Sebastião na região de Campos-Ibimirim são de origem fluvial e eólica (Figuras 19, 20). Os estratos eólicos incluem: formas de duna de grande escala com lâminas de risca de agulha (laminação pinstripe), sets com queda de grãos (grainfall) e fluxo de grãos (grainflow) (Figuras 11I, J, 19), depósitos de lençóis de areia dominados por lâminas de ondulação de vento (Figuras 16A, D) e depósitos de interduna eólicas. Os depósitos fluviais compreendem unicamente depósitos fluviais efêmeros canalizados.

Com relação ao ambiente eólico, as estruturas sedimentares e características descritas acima comparam favoravelmente àquelas observadas em areias de dunas modernas e em arenitos antigos interpretados como depósitos eólicos. Especificamente, a presença de estruturas como laminação pinstripe repetitiva com fluxo de grãos (grain flow) e queda de grãos (grain fall), bem como de laminação cruzada cavalgante subcrítica transladante (Figuras 11, 13, 15, 16), são consideradas diagnósticas de sedimentação eólica (Hunter, 1977a, b, 1981; Kocurek \& Dott, 1981; Fryberger \& Schenk, 1988; Kocurek, 1996; LeTourneau \& Huber, 1997; Mountney, 2006). Outras características sedimentares mais gerais sustentam interpretação eólica quando confrontadas com as estruturas acima mencionadas. Estas incluem boa seleção, alta porosidade primária e permeabilidade, tipos de superfícies delimitadoras hierárquicas, estratificações de grande escala e slump sheets (por exemplo, Hunter, 1977a, b, 1981; Fryberger et al., 1979; McKee, 1979a, b; Kocurek e Dott, 1981).

A intercalação de camadas de dunas eólicas com depósitos fluviais, chamada de interação flúvio-eólica, permite duas interpretações distintas, de acordo com Herries (1993), Scherer \& Lavina (2005): (i) deposição fluvial nas saliências de interdunas, simultânea ao 
preenchimento de dunas eólicas em outro lugar, com reposicionamento autocíclico dos canais fluviais e dunas ao longo do tempo ou (ii) deposição fluvial promovida pela suspensão da sedimentação eólica em ampla bacia e o natural desenvolvimento de extensa planície aluvial. A julgar pelas exposições da Formação São Sebastião, nas quais os depósitos fluviais em geral acham-se posicionados em meio às dunas eólicas e os resultados apresentados, favorecem à interpretação (i), de deposição fluvial nas depressões interdunas, contemporânea ao

(m) Estrut. sedim. Litofacies preenchimento de dunas eólicas em outra porção da bacia, com reposicionamento autocíclico dos canais fluviais e dunas ao longo do tempo. Este parece ter sido o processo interativo que atuou na sedimentação flúvio-eólica da Formação São Sebastião. Processos autocíclicos devem produzir depósitos alternando unidades eólicas e fluviais ao relacionar superfícies regionais erosivas e ao separar episódios deposicionais distintos dentro da bacia (Herries, 1993; Veiga et al., 2002; Mountney \& Jagger, 2004; Scherer \& Lavina, 2005).

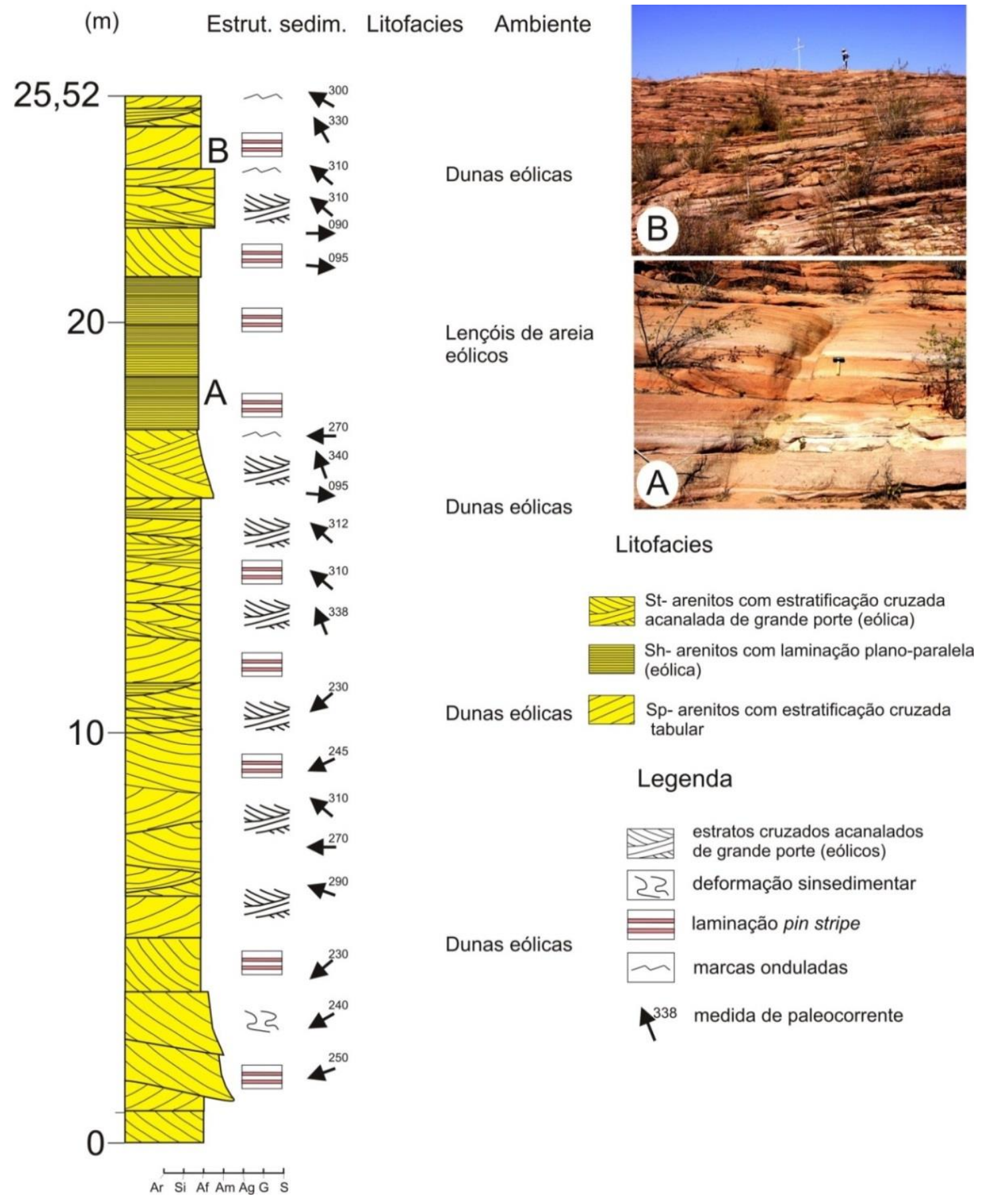

Figura 19 - Seção colunar de detalhe dos depósitos de dunas eólicas da Formação São Sebastião. A) foto de detalhe dos arenitos com laminação plano-paralela e pinstripe típicos de fácies de lençóis de Dunas Eólicas; B) estratificações cruzadas acanaladas de grande porte. Ponto 05. 
(m) Litologia/Facies Ambiente

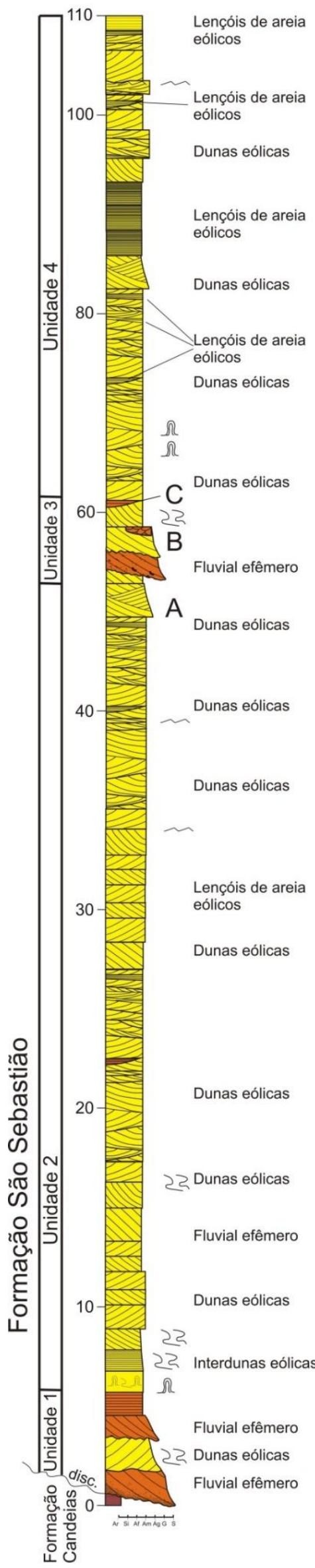

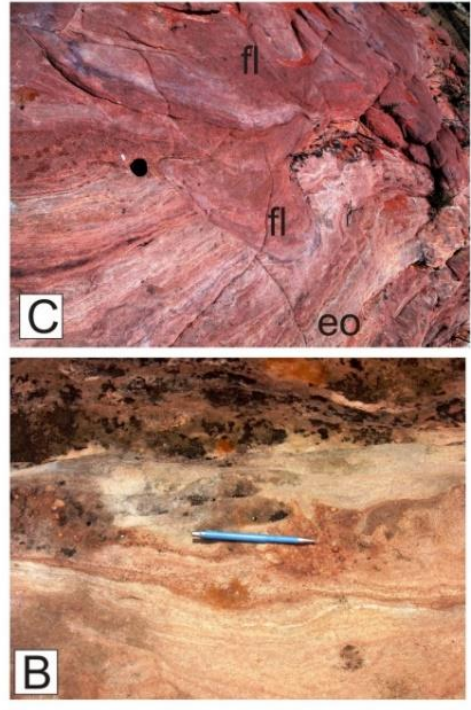

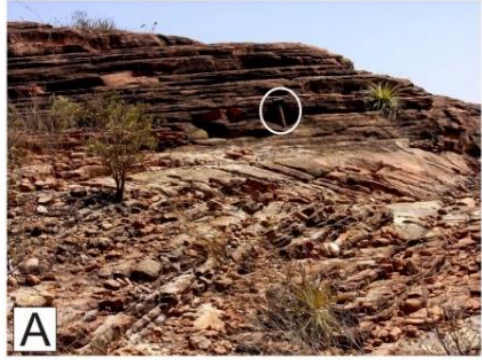

Litofacies

$E=$ Fm- argilitos avermelhados laminados

Fl- siltitos laminados

Sp-arenitos com estratificação cruzada tabular (eólica)

$22 \Omega$ Sd-arenitos com laminação deformada

$\$$ St- arenitos com estratificação cruzada acanalada de grande porte (eólica)

Sh-arenitos com laminação plano-paralela (eólica)

Sp-arenitos com estratificação cruzada tabula

Sh-arenitos com estratificação plano-paralela

St- arenitos com estratificação cruzad acanalada (fluvial)

Scg-arenitos conglomeráticos de grânulos e seixos pequenos

Legenda

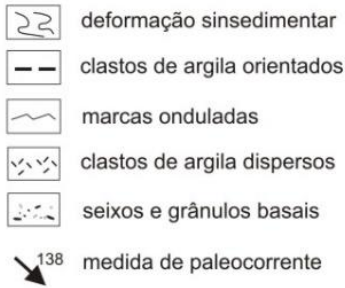

Tamanho dos grãos

Ar - argila

Si - silte

Af - areia fina

Am - areia média

$\mathrm{Ag}$ - areia grossa

G - grânulos

- seixos

Figura 20 - Seção colunar composta dos depósitos flúvio-eólicos da Formação São Sebastião. A) arenitos com estratificação cruzada acanalada de grande porte típicos da associação de lençóis de Dunas Eólicas; B) detalhe de nível fluvial marcado por arenitos grossos com seixos; C) contato erosivo entre depósitos fluviais efêmeros (fl) e eólicos (eo). 
De maneira expressiva, os depósitos de dunas eólicas e fluviais entrelaçados de natureza efêmera exibidos nos afloramentos analisados da Formação São Sebastião interdigitam-se e, por conseguinte, sugerem fortemente controle autocíclico na sedimentação (Figura 20). De fato, diversas intercalações contemporâneas entre depósitos fluviais efêmeros canalizados e dunas eólicas e depósitos interduna e de lençóis eólicos foram observadas na área investigada (Figura 20). Estas interações são mais comuns na base, na Unidade 1, e depois na Unidade 3, mas ocorrem em toda a seção investigada. Outra constatação que reforça essa interpretação é a recorrente ocorrência de arenitos deformados em depósitos de lençóis eólicos, reforçando a interação flúvio-eólica.

Como exemplo de modelo existe o caso do Permiano de Cedar Mesa (Utah, EUA) que evidencia sedimentação em margem de erg assinalada pela estreita associação de depósitos fluviais e eólicos (e.g. Langford \& Chan, 1988, 1989; Mountney \& Jagger, 2004). Uma característica exemplar dos arenitos de Cedar Mesa é a presença de várias supersuperfícies de escala local para regional, com a distinção da sucessão em 15 unidades genéticas eólicas. Muitas das quais apresentam superfícies de deflação e de interduna eólicas, como nos arenitos da Formação São Sebastião.

A mudança no estilo deposicional de sistema fluvial entrelaçado efêmero para sistema desértico, com amplo domínio de processos eólicos, a despeito de interações fluviais ao longo da seção, sugere importante mudança climática de condições relativamente úmidas para configurações mais áridas em direção ao topo. Em rochas mais antigas flúvio-eólicas da Bacia do Recôncavo Scherer et al. (2007) obtiveram resultados e conclusões semelhantes.
O conjunto de características litológicas e estruturais dos arenitos São Sebastião indica ambiente de sedimentação inicialmente fluvial (Unidade 1), com posterior retrabalhamento por vento (Unidades 2, 3 e 4), onde a porção basal caracteriza um sistema fluvial de alta energia, e as superiores, um ambiente desértico, tipicamente eólico, com interações flúvioeólicas. Os afloramentos a SSW do povoado de Campos constituem um verdadeiro campo de dunas (erg), com diversas exposições de excelente valor didático.

Bruni et al. (1976) apontaram que o contato inferior da Formação São Sebastião com os sedimentos do Grupo Ilhas seria transicional, enquanto que o superior com a Formação Marizal seria do tipo discordante erosivo/angular. No entanto, as mencionadas unidades não afloram na área estudada. Em adição, como ficou demonstrado, o contato inferior com a Formação Candeias (Figuras 5 e 20) é discordante erosivo.

De idade eocretácica, a Formação São Sebastião representa a última unidade estratigráfica na Bacia do Jatobá, da sequência Rifte de Guzmán-González et al. (2015a).

Esta interpretação para a Formação São Sebastião na Bacia de Jatobá implica que esta unidade, típica da fase final de desenvolvimento do rifte do sistema tafrogênico RecôncavoTucano-Jatobá, representaria uma das fases terminais do preenchimento deste sistema, com a colmatação da bacia por sistemas eólicos e fluviais que drenavam para sul e sudoeste áreas fontes localizadas a norte e a leste, em direção à Bacia de Tucano Norte e, nesta, em direção à Bacia do Recôncavo, a sudeste. Este fato demonstra que a região do rifte comportava-se como uma depressão contínua no Cretáceo Inferior recebendo sedimentos em uma estreita bacia com padrão de dispersão fluvial para sul.

\section{CONCLUSÕES}

1) Os estratos de arenitos da Formação São Sebastião na região de Campos-Ibimirim são de origem fluvial e eólica;

2) A Formação São Sebastião, na área investigada, ocorre diretamente sobre a Formação Candeias, e não sobre o Grupo Ilhas;

3) O conjunto de características sedimentológicas dos arenitos da Formação São Sebastião indica ambiente de sedimentação inicialmente fluvial, com posterior retrabalhamento por vento, onde a porção basal caracteriza um sistema fluvial de alta energia, e a superior, um ambiente desértico, tipicamente eólico, com interações fluviais. Os afloramentos a SSW do povoado de Campos constituem-se em verdadeiro campo de dunas (erg), com diversas exposições de excelente valor didático e científico;

4) A Formação São Sebastião representa a interação de dois sistemas deposicionais: eólico 
e fluvial. O sistema eólico indica variações climáticas, constatadas nas associações de fácies presentes. A Associação de Fácies de Dunas Eólicas idealiza clima mais seco. Ao passo que as associações de fácies de interduna eólicas sugerem clima mais úmido. A Associação de Fácies de Lençóis de Areia representa, igualmente, condições de aridez climática;
5) A mudança no estilo deposicional de sistema fluvial entrelaçado efêmero para sistema desértico, com amplo domínio de processos eólicos, a despeito de interações fluviais consideráveis na seção, sugere importante mudança climática - de condições relativamente úmidas para configurações mais áridas em direção ao topo.

\section{AGRADECIMENTOS}

Este trabalho contou com auxílio financeiro do Conselho Nacional de Pesquisas do Brasil - CNPq (Processo 480275/2012-2 concedido em nome de Edson V. Oliveira) a quem agradecemos o apoio e também as bolsas concedidas (bolsa de produtividade em pesquisa de V.H.M.L. Neumann e de Edson V. Oliveira, e de mestrado de Patrícia Celeste Lopes Jesuíno). Ao Programa de Recursos Humanos da Agência Nacional de Petróleo, Gás Natural e Biocombustíveis do Brasil (PRH26/ANP/FINEP/UFPE) pela bolsa de José Acioli B. Menezes Filho (PRH-26/ANP) e pelo suporte nos trabalhos de campo. À Profa. Dra. Alcina Magnólia F. Barreto (DGEO-UFPE) pela assistência nos trabalhos de campo. Agradecemos também à CPRM (Superintendência de Recife, SUREGRecife) pela disponibilização de fotografias aéreas, mapas e material utilizado no artigo. Ao Laboratório de Geologia Sedimentar e Ambiental (LAGESE/DGEO/UFPE) pelo apoio logístico e material. Agradecimentos são devidos, ainda, ao Departamento de Geologia, e aos alunos da disciplina Geologia de Campo 1, em especial Breno Hiphólito da Costa e Sidney Tesser Jr.

Agradecimentos são devidos ainda à Revista Geociências, na pessoa do Editor Prof. Dr. Norberto Morales, bem como aos revisores, pelas valiosas sugestões que em muito aprimoraram o manuscrito.

\section{REFERÊNCIAS}

AHLBRANDT, T.S. \& FRYBERGER, S.D. Sedimentary features and significance of interdunes deposits. In: ETHRIDGE, F.G.; FLORES, R.M. (Eds.). Recent and ancient nonmarine Depositional Environments. Society of Economic Paleontologists and Mineralogists, p. 293-314, 1981.

ARAGÃO, M.A.N.F. \& PERARO, A.A. Elementos estruturais do rifte Tucano/Jatobá. In: SIMPÓSIO SOBRE O CRETÁCEO DO BRASIL, 3, 1994, Rio Claro. UNESP, Boletim... Rio Claro: Sociedade Brasileira de Geologia, 1994p. 161-165.

ASSINE M.L. Paleocorrente, s e paleogeografia na Bacia do Araripe, nordeste do Brasil. Revista Brasileira de Geociências, v. 24, n. 4, p. 223-232, 1994.

BARBOSA, O. Geologia de parte da região do médio São Francisco, Nordeste do Brasil. Petrópolis: PROSPEC, 69 p., 1964.

BARRETO, P.M.C. O Paleozoico da Bacia do Jatobá. Boletim da Sociedade Brasileira de Geologia, v. 17, n. 1, p. 29-45, 1968.

BRAUN, O.P.G. Estratigrafia dos Sedimentos da Parte Inferior da Região Nordeste do Brasil (Bacias do Tucano-Jatobá, Mirandiba e Araripe). Rio de Janeiro, Divisão de Geologia e Mineralogia/DNPM (Boletim no 236), 75 p., 1966.

BRIDGE, J.S. Fluvial fácies models: recent developments. In: POSAMENTIER, H.W.; WALKER, R.G. (Eds.). Fácies Models Revisited. Oklahoma: Society for Sedimentary Geology, p. 85-170, 2006.

BROOKFIELD, M.E. The origin of bounding surfaces in ancient aeolian sandstones. Sedimentology, v. 24, p. 303-332, 1977.

BRUNI, M.A.L.; CORDANI, U.G.; CAMPOS, D.R.B CAMPOS, D.A. Carta Geológica do Brasil ao Milionésimo. Folha Aracaju (SC. 24). Brasília, DNPM/DGM. 226 p., 1976. CAIXETA, J.M., BUENO, G.V., MAGNAVITA, L.P., FEIJÓ, F.J. Bacias do Recôncavo, Tucano e Jatobá. Boletim de Geociências da Petrobrás, v. 8, n. 1, p. 163-172, 1994.

CARVALHO, R.R.; NEUMANN, V.H.; FAMBRINI, G.L.; VIEIRA, M.M.; ROCHA, D.E.G.A. Origem e proveniência da sequência siliciclástica inferior da Bacia do Jatobá. Estudos Geológicos, v. 20, p. 113-127, 2010.

CARVALHO, R.R.; NEUMANN, V.H.M.L; FAMBRINI, G.L., ASSINE, M.L.; VIEIRA, M. M.; ROCHA, D.E.G.A.; RAMOS, G. M. S. 2018. The basal siliciclastic Silurian-Devonian Tacaratu Formation of the Jatobá Basin: analysis of facies, provenance and palaeocurrents. Journal of South American Earth Sciences, v.88, p. 94-106.

CHAKRABORTY, T. \& CHAUDHURI, A.K. Fluvial-aeolian interactions in a Proterozoic alluvial plain: Example from the Mancheral Quartzite, Sullavai Group, Pranhita-Godavari Valley, India. Geological Society London Special Publications, v. 72, n. 1, p. 127-141, 1993.

COJAN, I. \& THIRY M. Seismically induced deformation structures in Oligocene shallow-marine and aeolian coastal sands (Paris Basin). Tectonophysics, v. 206, p. 9-32, 1992.

COLLINSON, J.D. \& THOMPSON, D.B. Sedimentary structures. London, Unwin Hyman, 207 p. 1989.

COSTA, I.P.; BUENO, G.V.; MILHOMEM, P.S.; SILVA, H.S.R.L.; KOSIN, M.D. Sub-bacia de Tucano Norte e Jatobá. Boletim de Geociências da Petrobras, v. 15, n. 2, 445-453, 2007. DIAS, K.L.N. \& SCHERER, C.M.S. Cross-bedding set thickness and stratigraphic architecture of aeolian systems: An example from the Upper Permian Pirambóia Formation (Paraná Basin), southern Brazil. Journal of South American Earth Sciences, v. 25 , p. $405-415,2008$

EL-BAZ, F.; MAINGUE, M.; ROBINSON, C. Fluvio-aeolian dynamics in the north-eastern Sahara: the relationship between fluvial/aeolian systems and ground water concentration. Journal of Arid Environments, v. 44, p. 173-183, 2000.

FAMBRINI, G.L.; LIMA-FILHO, M.F.; COSTA, B.H.; JESUÍNO, P.C.L.; TESSER Jr., S. Sistemas fluviais entrelaçados de alta energia da Formação São Sebastião na Bacia de Jatobá, Nordeste do Brasil. In: CONGRESSO BRASILEIRO DE GEOLOGIA, 43, 2006. Aracaju. Anais...: Sociedade Brasileira de Geologia, 2006, p. 289. 
FAMBRINI, G.L.; LIMA-FILHO, M.; TESSER JR., S.; COSTA, B.H.; JESUÍNO, P.C.L.; VALENÇA, L.M.M.; NEUMANN, V.H. Paleocorrentes fluviais da Formação São Sebastião, Bacia de Jatobá, NE do Brasil. In: SIMPÓSIO DE GEOLOGIA DO NORDESTE, 22, 2007, Natal, Atas... Sociedade Brasileira de Geologia, 2007, p. 45.

FAMBRINI, G.L.; LEMOS, D.R.; TESSER Jr., S.; ARAÚJO, J.T.; SILVA-FILHO, W.F.; SOUZA, B.Y.C.; NEUMANN, V.H. Estratigrafia, Arquitetura Deposicional e Faciologia da Formação Missão Velha (Neojurássico-Eocretáceo) na ÁreaTipo, Bacia do Araripe, Nordeste do Brasil: Exemplo de Sedimentação de Estágio de Início de Rifte a Clímax de Rifte. Geologia USP, Série Científica, v. 11, p. 55-87, 2011.

FAMBRINI, G.L.; NEUMANN, V.H.; MENEZES-FILHO, J.A.B.; ROCHA, D.E.G.A.; DURVAL, L.G.; JESUÍNO, P.C.L. Fácies e sistemas deposicionais da Formação São Sebastião (Eocretáceo), Bacia de Jatobá, PE: contribuição à evolução geológica do Rifte Recôncavo-Tucano-Jatobá, Nordeste do Brasil. In: SIMPÓSIO DE GEOLOGIA DO NORDESTE, 25 , 2013, Gravatá. Boletim Gravatá: Sociedade Brasileira de Geologia, 2013, p. 176-177.

FAMBRINI, G.L.; NEUMANN, V.H.M.L.; GUZMÁNGONZÁLEZ, J.; OLIVEIRA, E.V.; PIOVESAN, E.K.; SIAL, A.N. Sequência de Início de Rifte (Grupo Brotas) da Bacia de Jatobá: resultados preliminares. In: CONGRESSO BRASILEIRO DE GEOLOGIA, 48, 2016, Porto Alegre. Anais... Porto Alegre: Sociedade Brasileira de Geologia, 2016, Meio digital.

FAMBRINI, G.L., NEUMANN, V.H.M.L; MENEZES-FILHO, J.A.B, SILVA-FILHO, W.F.; OLIVEIRA, E.V. 2017. Facies architecture of fluvial Missão Velha Formation (NeojurassicEocretaceous), Araripe Basin, Northeast Brazil: paleogeographic and tectonic implications. Acta Geologica Polonica, 4, 515-545. DOI: 10.1515/agp-2017-0029.

FERRONATTO, J.P.F. Sucessão flúvio-eólica da Formação São Sebastião, Bacia de Jatobá - PE. Porto Alegre, 2016. 47 p. Dissertação (Mestrado)-Instituto de Geociências, Universidade Federal do Rio Grande do Sul.

FIGUEIREDO, F.T., ALMEIDA, R.P., FREITAS, B.T., MARCONATO, A., CARRERA, S.C., TURRA, B. 2016. Tectonic activation, source area stratigraphy and provenance changes in a rift basin: the Early Cretaceous Tucano Basin (NEBrazil). Basin Research, 28, 433-445.

FONSECA, J.I. Geological outline of the Lower Cretaceous Bahia Supergroup, Brazil. In: Proceedings of second west african micropaleontological colloquium. J.E. VAN HINTE (ed), Ibadan, 1966, p. 49-72

FREITAS, B.T.; ALMEIDA, R.P.; CARRERA, S.C.; FIGUEIREDO, F.T.; TURRA, B.B.; VAREJÃO, F.G.; ASSINE, M.L.. 2017. Aptian sedimentation in the RecôncavoTucano-Jatobá Rift System and its tectonic and paleogeographic significance" Journal of South American Earth Sciences, v.87, p. 460-481.

FRYBERGER, S.G.; AHLBRANDT, T.S.; ANDREWS, S. Origin, sedimentary features, and significance of low-angle Eolian "Sandsheet" deposits, Great Sand Dunes National Monument and vicinity, Colorado. Journal of Sedimentary Petrolology, v. 49, n. 3, p. 733-746, 1979.

FRYBERGER, S.G. \& SCHENK, C.J. Pinstripe lamination: a distinctive feature of modern and ancient eolian sediments. Sedimentary Geology, v. 55, p. 1-15, 1988.

GODINHO, L.P.S.; ALMEIDA, R.P.; SANTOS, M.G.M.; MARCONATO, A.; FRAGOSO-CESAR, A.R.S. Fácies sedimentares e elementos arquitetônicos das Formações Serra do Apertado e Pedra Pintada na Região das Minas do Camaquã -RS. Geologia USP, Série científica, v. 13, n. 2, p. 22-48, 2013.

GUZMÁN-GONZÁLEZ, J. Ostracodes e geoquímica das camadas carbonáticas da Formação Aliança da Bacia de Jatobá na localidade de Campos, Ibimirim-PE, Nordeste do
Brasil. Recife, 2015. 105p. Dissertação (Mestrado) Universidade Federal de Pernambuco.

GUZMÁN-GONZÁLEZ, J.; FAMBRINI, G.L.; USMA, C.C.; OLIVEIRA, E.V. Estratigrafia da Bacia de Jatobá: Estado da Arte. Estudos Geológicos, v. 25, p. 53-76, 2015a.

GUZMÁN-GONZÁLEZ, J.; PIOVESAN, E.K.; FAMBRINI, G.L.; OLIVEIRA, E.V. Non-marine ostracoda from Aliança Formation in the north-central portion of the Jatobá Basin, northeastern Brazil. Revista Brasileira de Paleontologia, v. 19 , p. $15-24,2016$.

GUZMÁN-GONZÁLEZ, J.; PIOVESAN, E.K.; OLIVEIRA, E.V.; SIAL, A.N.; FAMBRINI, G.L. O Andar local Dom João na Bacia de Jatobá: ostracodes, quimioestratigrafia e petrografia. In: CONGRESSO BRASILEIRO DE PALEONTOLOGIA, 24, 2015b, Crato, CE. Boletim de resumos - Paleontologia em Destaque, v. Ed. Esp. SBP, p. 103.

HERRIES, RD. Contrasting styles of fluvial-aeolian interaction at a downwind erg-margin: Jurassic Kayenta-Navajo transition, northeastern Arizona, USA. In: NORTH, C.P. AND PROSSER, D.J. (Eds), Characterization of fluvial and aeolian reservoirs. Geological Society London, Spec Publ., v.73, p. 199-218, 1993.

HJELLBAKK, A. Fácies and fluvial architecture of a high energy braided river: the Upper Proterozoic Seglodden Member, Varanger Peninsula, northern Norway. Sedimentary Geology, v. 114, p. 131-141, 1997.

HUNTER, R. Terminology of cross-stratified sedimentary layers and climbing-ripple structures. Journal of Sedimentary Petrology, v. 47, p. 697-706, 1977a.

HUNTER, R. Basic types of stratification in small eolian dunes. Sedimentology, v. 24, p. 361-387, 1977b.

HUNTER, R.E. Stratification styles in eolian sandstones: some Pennsylvanian to Jurassic examples from western interior U.S.A. In: ETHRIDGE, F.G. \& FLORES, R.M. (Eds.), Recent and Ancient Non marine Depositional Environments: Models for Exploration. SEPM Special Publication, v. 31, p. 315-329. 1981.

JAMES, N.P. \& DALRYMPLE, R.W. Fácies models 4. Geological Association of Canada, Geotext 6, 586 p, 2010.

JONES. J.; FROSTICK, L.E.; ASTON, T.R. Braided stream and flood plain architecture: the Rio Vero Formation, Spanish Pyrenees. Sedimentary Geology, v. 139, n. 3-4, p. 229-260, 2001. JONES, F.H.; SCHERER, C.M.S.; KUCHLE, J. Fácies architecture and stratigraphic evolution of aeolian dune and interdune deposits, Permian Caldeirão Member (Santa Brígida Formation), Brazil. Sedimentary Geology, v. 337, p. 133-150, 2016.

KOCUREK, G. Desert Aeolian systems. In: READING, H. G. (Ed.), Sedimentary Environments: Processes, Fácies and Stratigraphy. Blackwell Science, Oxford, p. 125-153, 1996.

KOCUREK, G. \& DOTT, R.H.J. Distinction sand uses of stratification types in the interpretation of eolian sands. Journal of Sedimentary Petrology, v. 51, n. 2, p. 579-595, 1981.

KOCUREK, G. \& FIELDER, G. Adhesion structures. Journal of Sedimentary Petrology, v. 52, p. 1229-1241, 1982.

KOCUREK, G. \& NIELSON, J. Conditions favourable for the formation of warm climate aeolian sand sheets. Sedimentology, v. 33, p. 795-816, 1986.

LANGFORD, R.P. \& CHAN, M.A. Fluvial-eolian interactions: Part II, ancient systems. Sedimentology, v. 36, p. 1023-1035, 1989.

LANGFORD, R.P. \& CHAN, M.A. Flood surfaces and deflation surfaces within the Cutler Formation and Cedar Mesa Sandstone (Permian), southeastern Utah. Geological Society of America Bulletin, v. 100, n. 10, p. 1541-1549, 1988.

LE HERON, D.P.; BUSLOV, M.M.; DAVIES, C.; RICHARDS, K.; SAFONOVA I. Evolution of Mesozoic fluvial systems along the SE flank of the West Siberian Basin, Russia. Sedimentary Geology, v. 208, p. 45-60, 2008 
LETOURNEAU, P.M. \& HUBER, P. Early Jurassic eolian dune field, Pomperaug basin, Connecticut and related synrift deposits: Stratigraphic framework and paleoclimatic context. Sedimentary Geology, v. 187, p. 63-81, 2006.

LETOURNEAU, P.M. \& HUBER, P. Early Jurassic rift basin eolian strata, Pomperaug basin, Newark Supergroup, Connecticut. Geological Society of America Abstracts, v. 29, n. 1, p. 61, 1997.

McKEE, E.D. Structures of dunes at the White Sands National Monument, New Mexico. Sedimentology, v. 7, p. 3-69, 1966.

McKEE, E.D. Introduction to a Study of Global Sand Seas. U.S. Geological Survey Professional Papers, v. 1052, p. 1-19, 1979a.

McKEE, E.D. Ancient sandstones considered to be eolian. In: McKee, E.D. (Ed.), A Study of Global Sand Seas, U.S. Geological Survey Professional Paper. U.S. Government Printing Office, Washington, 1979b.

McKEE, E.D. \& WEIR, G.W. Terminology for stratification and cross-stratification in sedimentary rocks. Geological Society of America Bulletin, v. 64, p. 381-390, 1953.

MAGNAVITA, L.P. Geometry and kinematics of the Recôncavo-Tucano-Jatobá Rift, NE Brazil. 1992. 492p. $\mathrm{PhD}$. Thesis. University of Oxford.

MAGNAVITA, L.P. \& CUPERTINO, J.A. Concepção atual sobre as bacias de Tucano e Jatobá, Nordeste do Brasil. Boletim de Geociências da Petrobrás, v. 1, n. 2, p. 119-134, 1987.

MAGNAVITA, L.P.; DAVISON, I. \& KUSZNIR, N.J. Rifting, erosion, and uplift history of the Recôncavo-Tucano-Jatobá Rift, northest Brazil. Tectonics, v. 13, n. 2, p. 367-388, 1994.

MAGNAVITA, L.P.; SZATMARI, P.; CUPERTINO, J.A.; DESTRO, N.; ROBERTS, D.G. The Recôncavo Basin. In DAVID, G.; ROBERTS, D.G.; BALLY, A.W. (eds.) Regional Geology and Tectonics: Phanerozoic Rift Systems and Sedimentary Basins. Amsterdam, Elsevier Science, p. 383420, 2012.

MIALL, A.D. A review of the braided-rivers depositional environment. Earth Science Review, v. 13, p. 1-62, 1977.

MIALL, A.D. Lithofácies types and vertical profile models in braided-rivers deposits: a summary. In: MIALL A.D. (ed.) Fluvial Sedimentology. Calgary, Canadian Society of Petroleum Geologists. (Canadian Society of Petroleum Geologists Memoir, n. 5), p. 597-604, 1978.

MIALL, A.D. Analysis of fluvial depositional systems. AAPG Educational Course Note Series, p. 1-75. (American Association of Petroleum Geologists Special Publication 20) 1981.

MIALL, A.D. Architectural- element analysis: a new method of fácies analysis applied to fluvial deposits. Earth Science Reviews, v. 22, p. 261-308, 1985.

MIALL, A.D. Architectural elements and bouding surfaces in fluvial deposits: anatomy of the Kayenta Formation (Lower Jurassic) Southwest Colorado. Sedimentary Geology, v. 55, p. 233-262, 1988.

MIALL, A.D. The geology of fluvial deposits: sedimentary fácies, basin analysis and petroleum geology. Berlin, Springer, 582 p, 1996.

MIALL, A.D. Principles of sedimentary basin analysis. $3^{\text {trd. }}$ ed., New York, Springer-Verlag, 616 p, 2000.

MIALL, A.D. Fluvial Depositional Systems. Berlin, Springer (Geology), 316 p, 2014.

MIALL, A.D. \& JONES B.G. Fluvial architecture of the Hawkesbury Sandstone (Triassic), near Sydney, Australia. Journal of Sedimentary Research, v. 73, n.4, p. 531-545, 2003.

MILANI, E.J. \& DAVISON, I. Basement control and transfer tectonics in the Recôncavo-Tucano-Jatobá rift, Northeast Brazil. Tectonophysics, v. 154, p. 41-70, 1988.

MILLS, P.C. Genesis and diagnostic value of soft-sediment deformation structures: a review. Sedimentary Geology, v. 35, p. 83-104, 1983.
MOHINDRA, R. \& THAKUR, V.C. Historic large earthquakeinduced soft sediment deformation features in the SubHimalayan Doon valley. Geological Magazine, v. 135, n. 2, p. 269-281, 1998.

MORETTI, M. Soft-sediment deformation structures interpreted as seismites in middle-late Pleistocene aeolian deposits (Apulian foreland, southern Italy). Sedimentary Geology, v. 135, p. 167-179, 2000.

MOUNTNEY, N.P. Eolian fácies models. In: POSAMENTIER, H.W. \& WALKER, R.G. (Eds.). Fácies Models Revisited. Society for Sedimentary Geology, Special Publication, 84, p. 19-83, 2006.

MOUNTNEY, N.P. \& JAGGER, A. Stratigraphic evolution of an aeolian erg margin system: the Permian Cedar Mesa Sandstone, SE Utah, USA. Sedimentology, v. 51, p. 1-31, 2004.

MOUNTNEY, N.P. \& THOMPSON, D.B. Stratigraphic evolution and preservation of aeolian dune and damp/wet interdune strata: an example from the Triassic Helsby Sandstone Formation, Cheshire Basin, UK. Sedimentology, v. 49, p. 805-834, 2002.

NEUMANN, V.H.M.L. \& ROCHA, D.E.G.A. Stratigraphy of the Post-Rift Sequences of the Jatobá Basin, Northeastern Brazil. In: ROCHA, R.; PAIS, J.; KULLBERG, J.C.; FINNEY, S. (Eds.). Strati 2013. Cham: Springer International Publishing, 2014. p. 553-557.

NEUMANN, V.H.M.L; ROCHA, D.E.G.A.; MORAES, A.S.; SIAL, A.N.; TABOADA-CASTRO, M.T.; BARBOSA, J.A.; FAMBRINI, G.L.; CARVALHO, R.R. Microfácies carbonáticas e comportamento isotópico de $\mathrm{C}$ e $\mathrm{O}$ nos calcários laminados aptianos lacustres da Serra Negra, Bacia do Jatobá. Estudos Geológicos, v. 20, n. 1, p. 89-100, 2010.

NEUMANN, V.H.M.L.; ROCHA, D.E.G.A.; VORTISCH, W.; GRATZER, R.; LIMA-FILHO, M.; BARBOSA, J.A.; FAMBRINI, G.L. Sedimentary Fácies and Palaeoenvironmental Records of an Intracratonic Basin Lake: Aptian Lacustrine Crato Formation, Jatobá Basin, NE Brazil. In: AAPG Annual Convention and Exhibition. Pittsburgh: AAPG@2013, v. 50882.

OBERMEIER, J.F.; JACOBSON, R.B.; SMOOT, J.P.; WEEMS, R.E.; GOHN, G.S.; MONROE, J.E.; POWARS, D.S. Earthquake-induced liquefaction features in the coastal setting of South Carolina and the fluvial setting of the New Madrid seismic zone. U. S. Geological Survey Professional Paper, v. 1504, 44p, 1990.

PAIM, P.S.G. \& SCHERER, C.M.S. High-resolution stratigraphy and depositional model of wind- and water-laid deposits in the ordovician Guaritas Rift (Southernmost Brazil). Sedimentary Geology, v. 202, p. 776-795, 2007.

PERARO, A.A. Caracterização sísmica do tectonismo transcorrente na Bacia do Jatobá. In: CONGRESSO INTERNACIONAL DA SOCIEDADE BRASILEIRA DE GEOFÍSICA, 4, 1995, Rio de Janeiro. Resumos expandidos... Sociedade Brasileira de Geofísica, 1995, p. 1-3.

POTTER, P.E. \& PETTIJOHN, F.J. Paleocurrents and Basin Analysis. Springer Verlag, $2^{\text {nd }}$ ed., p. 425, 1977.

READING, H.G. Sedimentary environments: processes, fácies and stratigraphy. Blackwell Science, 668 p, 1996.

RICCOMINI, C.; CHAMANI, M.A.C.; AGENA, S.S.; FAMBRINI, G.L.; FAIRCHILD, T.R.; COIMBRA, A.M. Earthquake-induced liquefaction features in the Corumbataí Formation (Permian, Paraná Basin, Brazil) and the dynamics of Gondwana. Anais da Academia Brasileira de Ciências, v. 64, n. 3, p. 210, 1992.

ROCHA, D.E.G.A. Caracterização do intervalo carbonático aptiano da Bacia do Jatobá, NE do Brasil. Recife, 2011. 124 p. Tese (Doutorado)-Centro de Tecnologia e Geociências, Universidade Federal de Pernambuco.

ROCHA, D.E.G.A. \& AMARAL, C.A. Caracterização Geológica e Geométrica dos Aquiferos (Meta B). In: COSTA, W. D \& FEITOSA, F. A. C (Coords). Hidrogeologia da Bacia 
Sedimentar do Jatobá: Sistema Aqüífero Tacaratu/Inajá. Ministério de Minas e Energia. 2007.

ROCHA, D.E.G.A. \& LEITE, J.F. Mapa geológico da Bacia do Jatobá - Geologia. Recife. CPRM 2001.

ROCHA, D.E.G.A. \& LEITE, J.F. Estudo Hidrogeológico da Bacia do Jatobá - Geologia. Recife. CPRM. 1999.

SCHANLEY, K.W. \& McCABE, P.J. Perspectives on the sequence stratigraphy of continental strata. American Association Petroleum Geology Bulletin, v. 78, p. 544-568, 1994.

SCHERER, C.M.S.; LAVINA, E.L.C.; DIAS FILHO, D.C.; OLIVEIRA, F.M.; BONGIOLO, D.E.; AGUIAR, E.S Stratigraphy and fácies architecture of the fluvial-aeolianlacustrine Sergi Formation (Upper Jurassic), Recôncavo Basin, Brazil. Sedimentary Geology, v. 194, p. 169-193, 2007.

SCHERER, C.M.S. \& LAVINA, E.L.C. Sedimentary cycles and fácies architecture of aeolian-fluvial strata of the Upper Jurassic Guará Formation, southern Brazil. Sedimentology, v. 52, p. 1323-1341, 2005.

SELLEY, R.C. Applied sedimentology environments, a brief survey. London, Academic Press. 2000.

SILVA, K.S.; OLIVEIRA, E.V.; BARRETO, A.M.F.; FAMBRINI, G.L.; PIOVESAN, E.K. Microvertebrados do Grupo Santo Amaro superior, Eocretáceo da Bacia de Jatobá, Nordeste do Brasil. In: CONGRESSO BRASILEIRO DE PALEONTOLOGIA, 24, 2015, Crato, CE. Boletim de resumos - Paleontologia em Destaque, 2015. v. Ed. Esp., p. 199.

SPALETTI, L.A.; LIMARINO, C.O.; COLOMBO PIÑOL, F. Internal anatomy of an erg sequence from the aeolian-fluvial system of the De La Cuesta Formation (Paganzo Basin, northwestern Argentina). Geologica Acta, v. 8, n. 4, p. 431447, 2010.

UPADHYAY, R. Earthquake-induced soft sediment deformation in the lower Shyok river valley, northern Ladakh, India. Journal of Asian Earth Sciences, v. 21, n. 4, p. 413-421, 2003. VAREJÃO, F.G.; PERINOTTO, J.A.J. NEUMANN, V.H.M.L.; FREITAS, B.T.; ALMEIDA, R.P.; ASSINE M.L. Upper Aptian mixed carbonate-siliciclastic sequences from Tucano Basin, Northeastern Brazil: implications for paleogeographic reconstructions following Gondwana break-up. Cretaceous Research, v. 67, p. 44-58, 2016.
VEIGA, G.D. \& SPALETTI, L.A. The Upper Jurassic (Kimmeridgian) fluvial-aeolian systems of the southern Neuquen Basin, Argentina. Gondwana Research, v. 11, p. 286-302, 2007.

VEIGA, G.D.; SPALLETTI, L.A.; FLINT, S. Aeolian/fluvial interactions and high resolution sequence stratigraphy of a nonmarine lowstand wedge: the Avile Member of the Agrio Formation (Lower Cretaceous), central Neuquén Basin, Argentina. Sedimentology, v. 49, p. 1001-1019, 2002.

VIANA, C.F. Stratigraphic distribution of Ostracoda in the Bahia Supergroup (Brazil). In: WEST AFRICAN MICROPALEONTOLOGICAL COLLOQUIUM, SECOND, Ibadan, 1965. (ed) J.E. VAN HINTE). Proceedings... Ibadan: 1965, p. 240-257, 1966.

VIANA, C.F; GAMA JR., E.G.; SIMÕES, I.A.; MOURA, J.A.; FONSECA, J.R. \& ALVES, R.J. Revisão estratigráfica da Bacia do Recôncavo/Tucano. Boletim Técnico da Petrobrás, v. 14, ns. 3/4, p. 157-192, 1971.

WALKER, R.G. Fácies Models revisited: Introduction. In: POSAMENTIER, H.W. \& WALKER R.G. (eds) Fácies Models revisited, Society of Economic Paleontologists and Mineralogists (SEPM), Spec. Publ. 84, Tulsa, 532 p, 2006.

WALKER, R.G. Fácies, fácies models and modern stratigraphic concepts. In R.G. WALKER \& N.P. JAMES (Eds.), Fácies Models-Response to Sea-level Changes, Geological Association of Canada Geotext 1, pp. 1-14, Waterloo, Ontario. 1992.

WALKER, R.G. \& JAMES, N.P. Fácies models. Response to sea level changes. Geological Association of Canada, 212 p. 1992. 